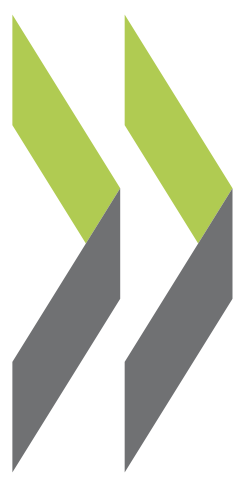

OECD Working Papers on Finance, Insurance and Private Pensions No. 41

\title{
Unleashing the Export \\ Potential of SMEs in Greece
}

\section{lota Kaousar Nassr,}

Virginia Robano, Gert Wehinger 


\section{OECD WORKING PAPERS ON FINANCE, INSURANCE AND PRIVATE PENSIONS}

OECD Working Papers should not be reported as representing the official views of the OECD or of its member countries. The opinions expressed and arguments employed are those of the authors.

Working Papers describe preliminary results or research in progress by the author(s) and are published to stimulate discussion on a broad range of issues on which the OECD works. Comments on Working Papers are welcomed, and may be sent to daf.contact@oecd.org or the Financial Affairs Division, Directorate for Financial and Enterprise Affairs, OECD, 2 rue AndréPascal, 75775 Paris Cedex 16, France.

OECD Working Papers on Finance, Insurance and Private Pensions provide timely analysis and background on industry developments, structural issues, and public policy in the financial sector, including insurance and private pensions. Topics include risk management, governance, investments, benefit protection, and financial education.

\section{OECD WORKING PAPERS ON FINANCE, INSURANCE AND PRIVATE PENSIONS}

are published on www.oecd.org/daf/fin/wp

This document and any map included herein are without prejudice to the status of or sovereignty over any territory, to the delimitation of international frontiers and boundaries and to the name of any territory, city or area.

The statistical data for Israel are supplied by and under the responsibility of the relevant Israeli authorities. The use of such data by the OECD is without prejudice to the status of the Golan Heights, East Jerusalem and Israeli settlements in the West Bank under the terms of international law.

\section{(c) OECD 2016}

You can copy, download or print OECD content for your own use, and you can include excerpts from OECD publications, databases and multimedia products in your own documents, presentations, blogs, websites and teaching materials, provided that suitable acknowledgment of OECD as source and copyright owner is given. All requests for commercial use and translation rights should be submitted to rights@oecd.org. 


\title{
Unleashing the Export Potential of SMEs in Greece to Help Jump-Start Economic Recovery
}

\author{
by \\ Iota Kaousar Nassr, Virginia Robano and Gert Wehinger, OECD
}

\begin{abstract}
Despite Greece's long history as a trading nation, the country is failing to live up to its export potential. Small and medium-sized enterprises (SMEs) could significantly contribute to strengthening Greece's export performance, thereby helping to jump-start economic growth and job creation as well as improving the sustainability of fiscal and external accounts. This paper explores aspects of the business, financial and regulatory environment that impede the greater involvement of SMEs in export activity. The paper also discusses the potential role of a development bank and stresses the importance of more R\&D and innovation, the need to develop venture and other equity capital financing, and the need to build stronger links and networks between universities and industry. It draws some policy conclusions and suggests policy measures in the areas of finance, regulation, $R \& D$ and innovation.
\end{abstract}

Authorised for release by Pierre Poret, Deputy Director, OECD Directorate for Financial and Enterprise Affairs

JEL Classification: F1, F43, F6, G2, H81, I23, L25, L26, M13, O3

Keywords: Greece, small and medium-sized enterprises (SMEs), SME finance, venture capital, entrepreneurship, business environment, export performance, research and development (R\&D), development banks. 


\section{TABLE OF CONTENTS}

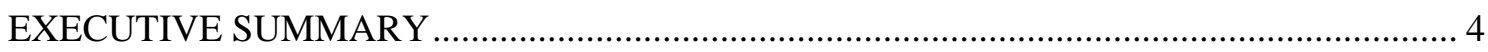

I. GREEK EXPORT ACTIVITY AND THE SME ENVIRONMENT ….................................. 6

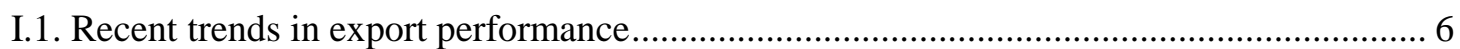

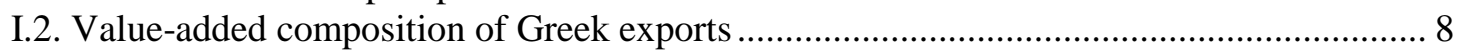

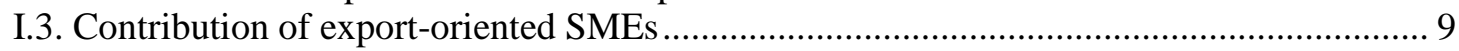

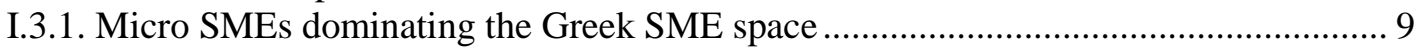

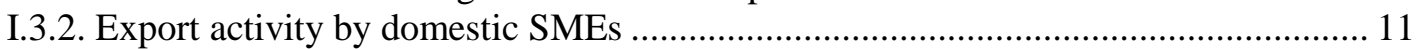

II. THE BUSINESS CLIMATE: TACKLING IMPEDIMENTS TO THE GREATER CONTRIBUTION OF GREEK SMES TO THE RECOVERY OF EXPORT ACTIVITY .. 12

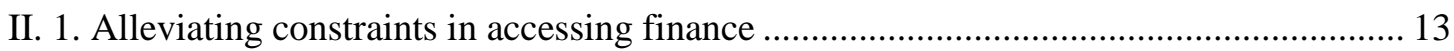

II.1.1. The importance of financing for exporting companies.............................................. 13

II.1.2. A growth model based on bank lending and the SME credit crunch ....................... 13

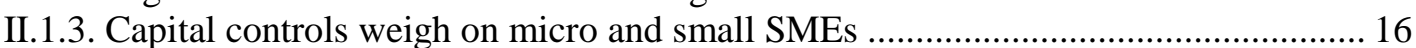

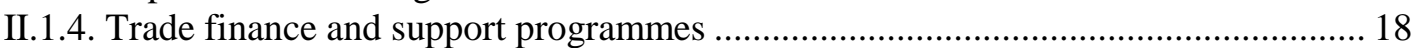

II.1.5. A potential role for a development bank in Greece................................................. 20

II.1.6. Developing equity financing and links between VC and university research ........... 22

II.1.7. Securitisation and capital market financing.............................................................. 23

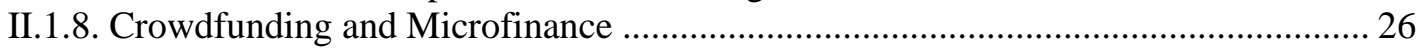

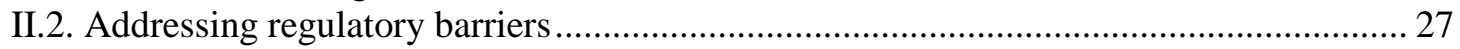

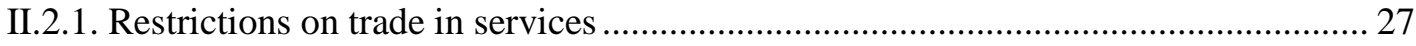

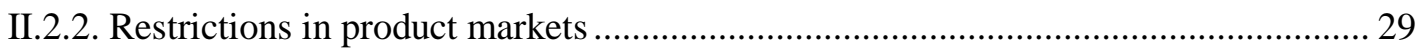

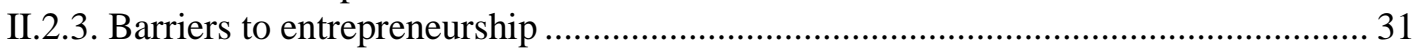

II.2.4. Reforms to tackle administrative opacity and reduce the cost of doing business...... 31

II.2.5. Effective dispute resolution mechanisms ............................................................. 33

III. PROMOTING R\&D AND INNOVATION FOR PRODUCT UPGRADING IN GVCS ... 34

III.1. A mismatch of low R\&D investment and a valuable stock of human capital............. 34

III.2. The triple helix of innovation, entrepreneurship and public policy and the role of

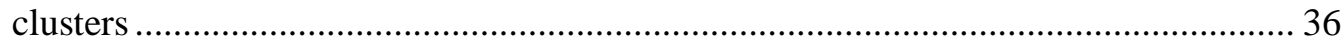

III.3. Diversification of the export base through a reorientation towards innovation and

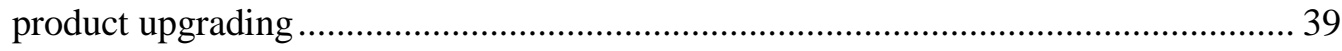

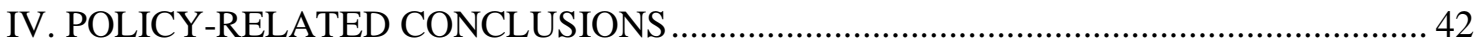

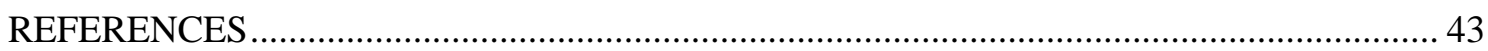

\section{Tables}

Table 1. A small number of SMEs has benefited from guarantees and counter-guarantees ... 19 


\section{Figures}

Figure 1. Weak export performance despite competitiveness gains ..................................... 6

Figure 2. Changes in unit labour costs and exports growth .............................................. 7

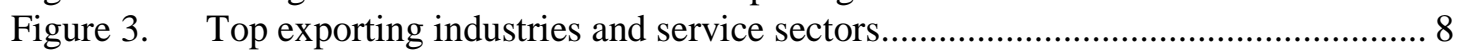

Figure 4. Foreign value added content of gross exports, 1995 vs. 2009............................. 9

Figure 5. Micro SMEs are the vast majority of businesses in Greece .............................. 10

Figure 6. Value added by enterprise size, total business economy ................................... 11

Figure 7. Micro SMEs dominating export activity …….............................................. 12

Figure 8. SME Lending growth and credit conditions.................................................... 15

Figure 9. Credit conditions for Greek SMEs remain tougher than for European peers...... 16

Figure 10. Micro and small SMEs reporting survival problems and deteriorating outlook . 17

Figure 11. Effect of capital controls on micro and small SMEs ......................................... 18

Figure 12. Greece a laggard in venture capital investment ............................................... 22

Figure 13. Outstanding Greek securitisation by collateral, as of Q4 2014 …..................... 25

Figure 14. All post-crisis Greek securitisation issuance was retained .................................. 25

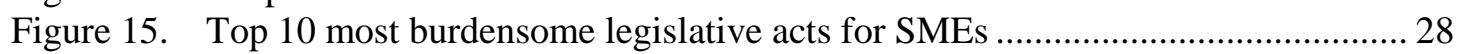

Figure 16. Greek Services Trade Restrictiveness Index by sector and policy area .............. 29

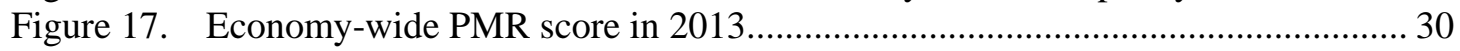

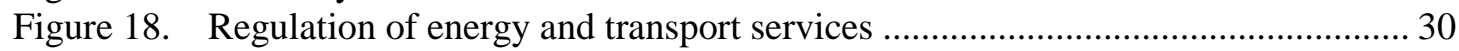

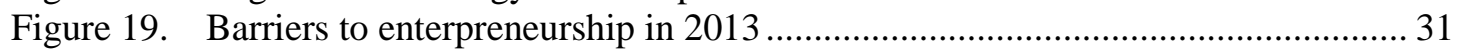

Figure 20. A valuable stock of human capital ................................................................. 34

Figure 21. Comparative performance of national science and innovation systems,

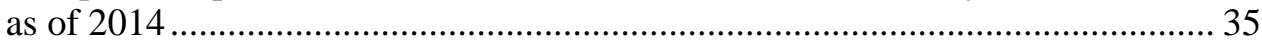

Figure 22. Positive attitudes towards entrepreneurship clouded by a high fear of failure.... 36

Figure 23. Services are key to the efficient operation of GVCs .............................................. 37

Figure 24. Participation of Greek firms in GVCs ……........................................................ 38

Figure 25. Low broadband penetration and e-commerce activity compared to other

OECD countries

\section{Boxes}

Box 1. Good practices for public financial institutions

Box 2. Results of the public consultation on the top 10 most burdensome legislative acts for SMEs

Box 3. Policy-related conclusions and potential policy action .............................................. 42 


\section{EXECUTIVE SUMMARY}

Weak export performance of the Greek economy predated the Greek sovereign debt crisis, despite the historical character of the country as a "trade nation". Lack of foreign direct investment, poor price competitiveness, insufficient product market reforms, regulatory barriers, bureaucracy and an insufficiently business-friendly environment have been some of the impediments behind lagging export activity. While reform efforts so far have already covered a lot of ground in terms of fiscal consolidation and cost competitiveness adjustment, further reforms are required for Greece to achieve its full exporting potential and address non-cost related weaknesses.

The export potential of Greece could be vast, given its history, cultural sites, key geographical location, natural beauty, abundant but insufficiently exploited renewable energy sources (wind and solar power), and a highly skilled and educated population. The benefits of comparative advantages in agriculture (for high quality products), tourism (including medical tourism and permanent retirement), and other services besides shipping (health, education, logistics, energy) are not fully exploited. The European Commission has tried to quantify Greece's export gap for the period 1995-2009, estimating that actual Greek value added exports were falling short by $33 \%$ of what regular international trade patterns would predict on basis of Greek's GDP, the size of its trading partners and their geographical distance for that period. Low institutional quality was found to explain large parts of this "missing exports puzzle" (Böwer et al., 2014).

Despite improvements in competitiveness due to radical adjustments in unit labour costs, competitiveness gains have failed to translate into equal increases in export performance. Although the overall business climate has significantly improved over the past five years, regulatory barriers to competition, administrative opacity and inefficient bureaucracy still remain to be addressed. More product market reforms that should improve competitive conditions and facilitate new entrants are already planned, together with policies to reduce the administrative burden and bureaucratic hurdles for businesses, in particular when it comes to exporting processes.

With prolonged weak domestic demand expected to persist, exports are best placed to jump-start economic growth and job creation and improve the sustainability of external accounts. The contribution of small and medium-sized enterprises (SMEs) in supporting a more export-oriented economy could be significant given the high proportion of SMEs in the firm population and their low export intensity that indicates unused potential to drive an export-led recovery and spearhead growth.

Greater participation of SMEs in global value chains (GVCs) and enhancement of the knowledge content of their products could allow for both the expansion of the export base and the upscaling of the complexity and quality of exported products ("product upgrading"), capturing more of the value added of exports. The diversification and expansion of exports in areas with growth potential like information technology, pharmaceuticals, medical tourism, education, cultural and creative industries, green tech and other technologies can be fostered through the reorientation of the export base towards investment in knowledge-based capital and innovation. 
Impaired financing channels to SMEs hamper their growth and discourage internationalisation and export growth. The reinforcement of the financial sector and the resolution of the non-performing loans exposure challenge is the prerequisite for the restoration of liquidity for SMEs. Simple, transparent and standardised securitisation of SME loans (and other liabilities) can be used as a market-based shortcut to indirectly foster SME financing without the complete disintermediation of banks. Other capital market financing instruments (bonds, private placements, listed equities) issued and traded on established tailor-made SME platforms with proportionate costs and requirements could be promoted as complementary to bank lending.

The implementation of a more efficient restructuring and resolution framework, coupled with improvements in the insolvency regime (underway), should allow for a quicker exit of insolvent SMEs and more efficient debt (but also operational) restructuring of viable SMEs. Putting in place mechanisms that allow SMEs a 'fresh start' could reduce the stigma associated with failure and promote entrepreneurial risk-taking.

Promotion of financial education for SMEs is key in order to raise awareness of existing official sector support programmes and of alternative financing instruments available to these companies, while equipping them with the skills necessary to make use of support schemes and/or alternative debt and equity financing instruments. The advisory role of a public financial institution could be further promoted to that end.

Greater emphasis should be placed on developing venture capital financing, and stronger links and networks need to be built between research at universities and other centres of innovation and venture capital suppliers. Research and innovation created by an existing stock of highly qualified human capital needs to be diffused and exploited through entrepreneurial activity around universities and research centres, catalysed by venture capital investment. The design and development of cluster policies and initiatives (including incubators) can support knowledge transfers and technology diffusion and potentially ease the flow of financing for participating companies, particularly in the form of venture capital that is currently underdeveloped.

Ultimately, the stabilisation of the political and economic environment will help to reduce uncertainty, rebuild trust and lift confidence of investors, financiers and companies. Certainty of the legal and regulatory environment and a stable tax framework in which these actors operate is a major part of that.

The report has been prepared as background paper for the 2016 OECD Economic Survey of Greece (OECD, 2016) and is structured as follows: Section I provides a high level overview of the overall export activity of the Greek economy and looks into the characteristics of SMEs in Greece and their contribution to the country's exports. Section II discusses the business climate and the financial and regulatory impediments to greater involvement of SMEs in export activity. Section III discusses the importance of greater R\&D and innovation for product upgrading and the need for links between research at universities and elsewhere and the industry. The concluding section distils some policy implications from the above and suggests policy measures that could address some of the challenges discussed. 


\section{GREEK EXPORT ACTIVITY AND THE SME ENVIRONMENT}

\section{I.1. Recent trends in export performance}

Exports of goods have increased at a much slower pace than in other European countries undergoing adjustment programmes, lagging behind the export-led recoveries those countries have enjoyed (OECD, 2013b). However, net exports of goods in Greece increased significantly since 2008, partly as a result of a sizeable and persistent import contraction, in line with reduction in domestic demand. At the same time, given that the import content of exports is about $30 \%$ - even though below the OECD average - such a decline in imports has a negative spillover effect on exports.

Total exports of Greek products and services regained momentum throughout 2014 (Figure 1), boosted by a record performance in the tourism sector and assisted by a generalised rebound in economic activity, investment as well as business and consumer confidence (OECD, 2015a). Notwithstanding this rebound, the export performance of the country remained very weak, not least because of a subsequent standstill that occurred in 2015. The upward trend of the economic sentiment index was reversed in the first months of 2015 and continued to deteriorate across the board and for all sectors, with the industrial confidence index dropping in May 2015 to levels lower than at the end of 2013 (IOBE, BoG, 2015).

Figure 1. Weak export performance despite competitiveness gains
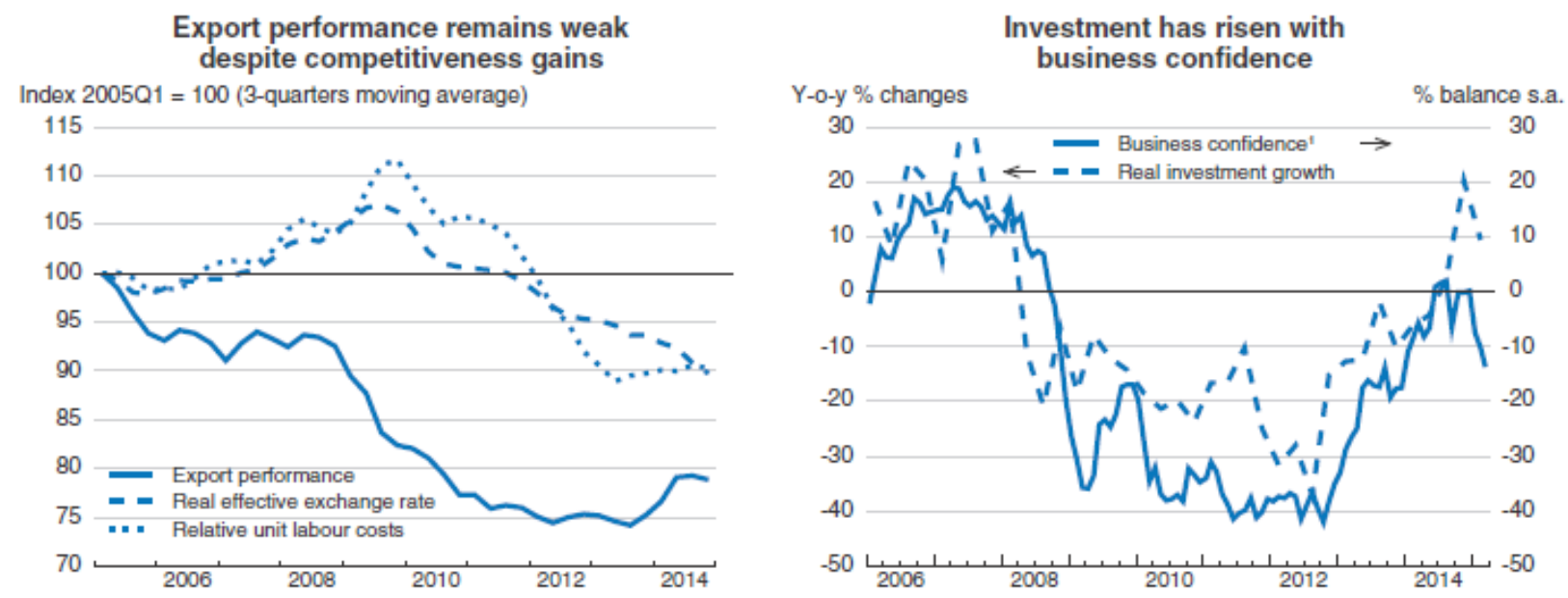

Source: Notes: 1. Unweighted average of data for manufacturing industry, construction, trade and business-related services. The export performance measures the gain (increase) or loss (decrease) in export market share.

Source: OECD (2015a), OECD Economic Outlook 97 database and OECD National Account Database.

Greek exporters failed to fully benefit from gains in competitiveness that resulted from the sharp adjustment of labour costs over the past six years (Figure 2). Although structural reforms in the 
product markets have already covered a lot of ground, reforms of the labour market were more extensive. As a consequence, the adjustment of labour costs has not been fully reflected in prices due inter alia to some remaining rigid market structures (OECD, 2013). Nevertheless, export activity overall is expected to continue to grow once the economic uncertainty is removed and financial conditions are normalised, supported by the recovery in external demand, the recent devaluation of the euro as well as the competitiveness gains of the past five years.

Figure 2. Changes in unit labour costs and export growth

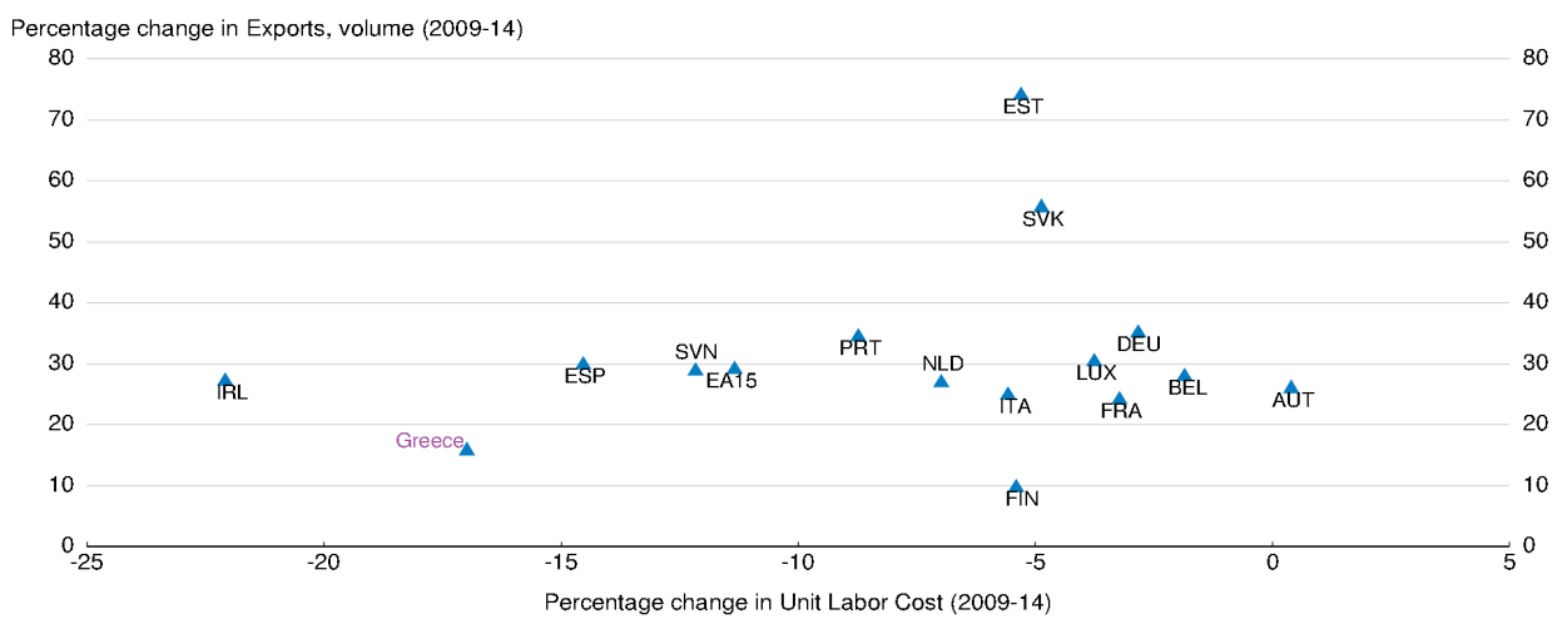

Source: OECD National accounts database.

The technological intensity of Greek export goods is low, with the top four exporting industries comprising refined petroleum products/fuel, basic metals (aluminium, copper, steel), food products/beverages/tobacco and agriculture (Figure 3). Exports of fuel (refined oil) are almost twice as high as the second largest exports sector (pharmaceuticals). Export of services account for 55\% of total exports with tourism constituting by far the largest part, followed by transport services (mainly shipping). Tourism, in particular, has benefited from better transport connectivity with countries of origin of tourists, an extension of the touristic season, the promotion of additional destinations within the country and improved conditions for cruise ships (increase in home porting, infrastructure investment in Pireaus port to that end). In terms of geographic exposure, Turkey is Greece's largest trading partner in gross exports, while Germany, the US, Italy, the UK and France are the largest export destinations when measuring export value-added. The largest part of the country's exports goes to EU partners, although the share of exports to non-European countries has been gradually increasing (e.g. Russia). 
Figure 3. Top exporting industries and service sectors

(A) Top goods export industries

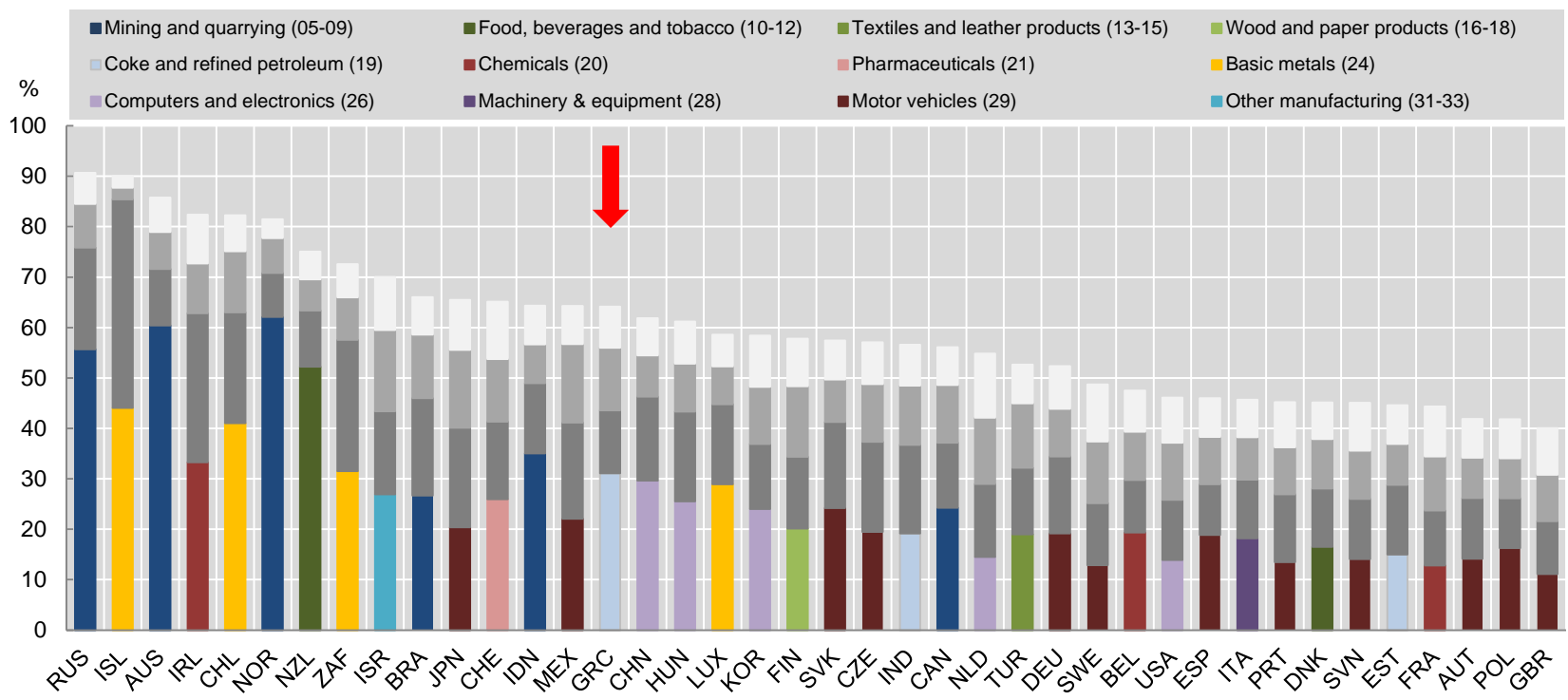

(B) Top services export sectors

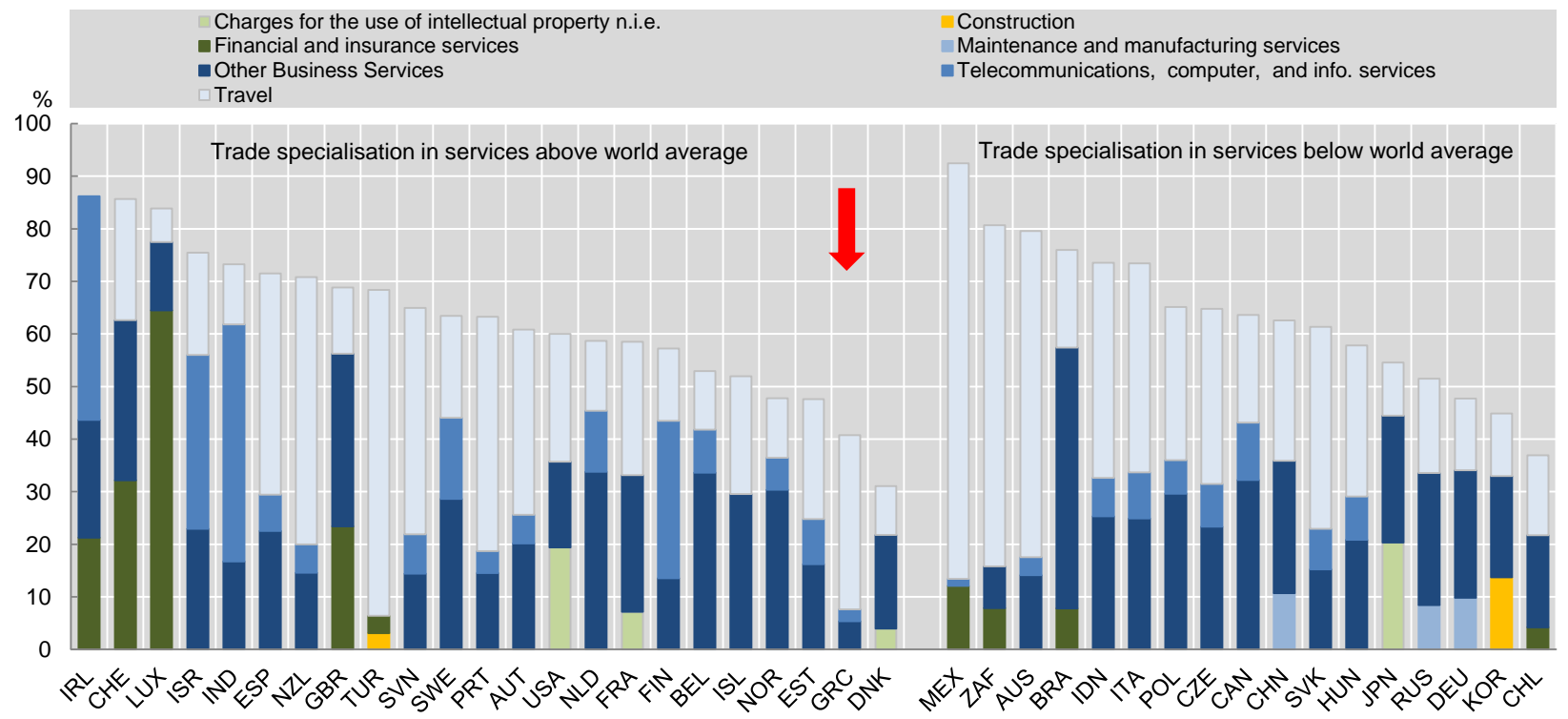

Source: OECD (2013a).

\section{I.2. Value-added composition of Greek exports}

The foreign content of Greek exports stands below the OECD average, mainly due to its high specialisation in services, and in particular tourism and transport (Figure 3B). Interestingly, this content has increased by almost $10 \%$ since 1995, demonstrating the increasing integration of Greek exports in global value chains (GVCs). The country's increasing integration in GVCs can also be seen in the rising share of imported intermediate inputs embodied in its exports following their incorporation in the production of goods and services (Figure 4). Services represent $74 \%$ of Greek 
exports in terms of value added but only 55\% of gross exports (OECD 2014a), indicating the importance of an efficient and productive services sector for the export performance of the country.

Figure 4. Foreign value added content of gross exports, 1995 vs. 2009

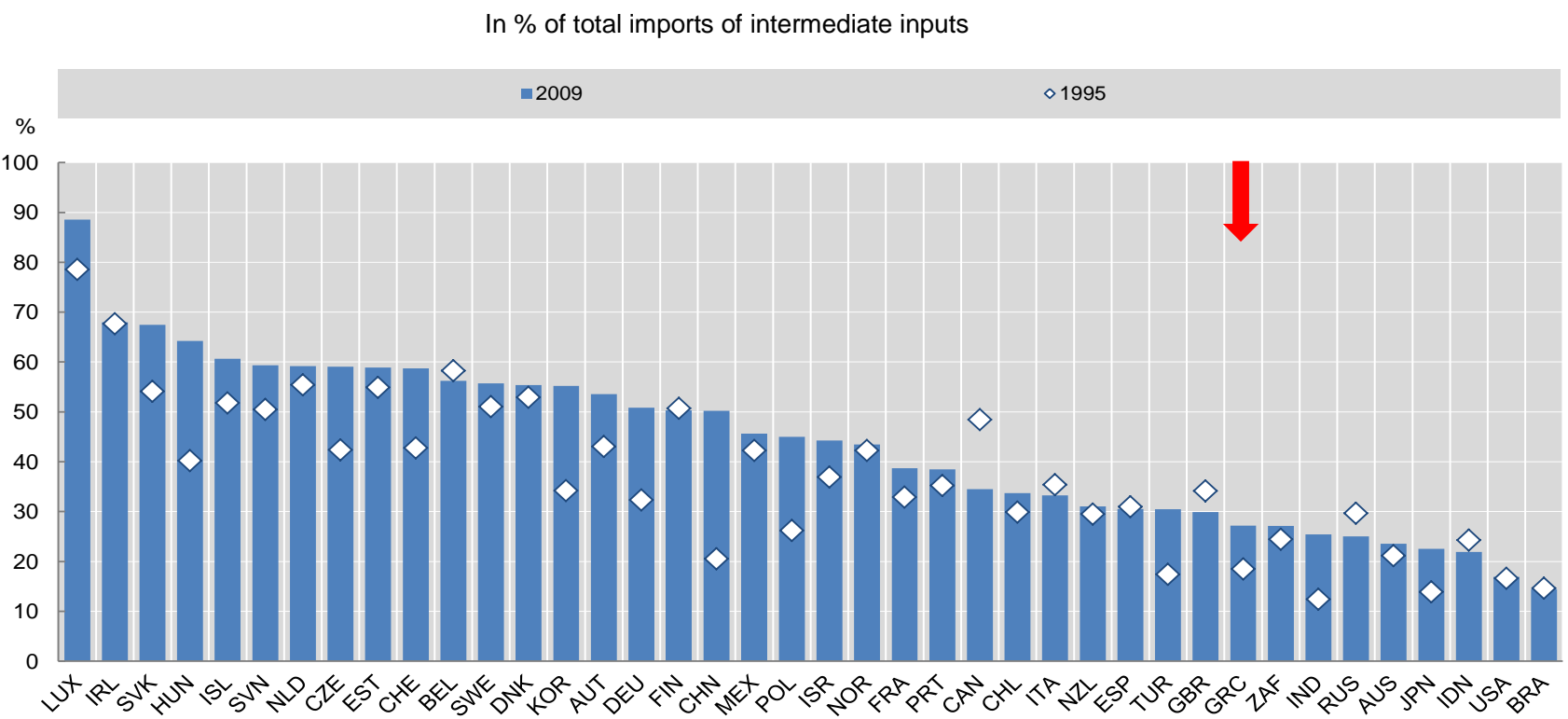

Source: OECD-WTO, Trade in Value Added (TiVA) Database, http://oe.cd/tiva, May 2013, OECD (2014a).

\section{I.3. Contribution of export-oriented SMEs}

\section{I.3.1. Micro SMEs dominating the Greek SME space}

Greece has one of the highest shares of micro SMEs in its business demography, with almost $97 \%$ of SMEs employing up to 9 people (Figure 5A). A large part of these are sole proprietorships, with almost $4 / 5$ of SMEs with a turnover of up to EUR $10 \mathrm{~m}$ belonging to auto-entrepreneurs, against $1 / 2$ in the European equivalent (NBG, 2014). The existence of some informal SMEs, particularly in the tourism sector, would add to the actual shares of micro SMEs and sole proprietorship in the total business population but is hard to quantify. Interestingly, the vast majority of micro-enterprises (79\%) are active in the services industry.

The distribution of employment is similarly skewed towards micro SMEs, with almost $60 \%$ of employment found in such micro-enterprises, the highest share amongst developed economies (Figure 5B). Although self-employment levels remain below pre-crisis levels as a consequence of bankruptcies and company failings, their number has begun to pick up in recent periods, outperforming overall employment growth. This could confirm anecdotal evidence suggesting that many of these micro SMEs are formed out of necessity as 'coping strategies' responding to pressing needs given the persisting high unemployment rates (26\%), particularly among the young population.

The importance of the SME sector and in particular of micro-enterprises for the Greek economy is further demonstrated by looking at the distribution of total turnover by enterprise size. While microSMEs in OECD countries account on average for $20 \%$ of total turnover, in Greece they are responsible for $37 \%$ of total turnover, with the respective turnover shares for all SMEs standing at $60 \%$ on average for OECD countries vs. $75 \%$ in Greece. 
Figure 5. Micro SMEs are the vast majority of businesses in Greece

(A) Number of enterprises by size in percent of total, 2012 or latest

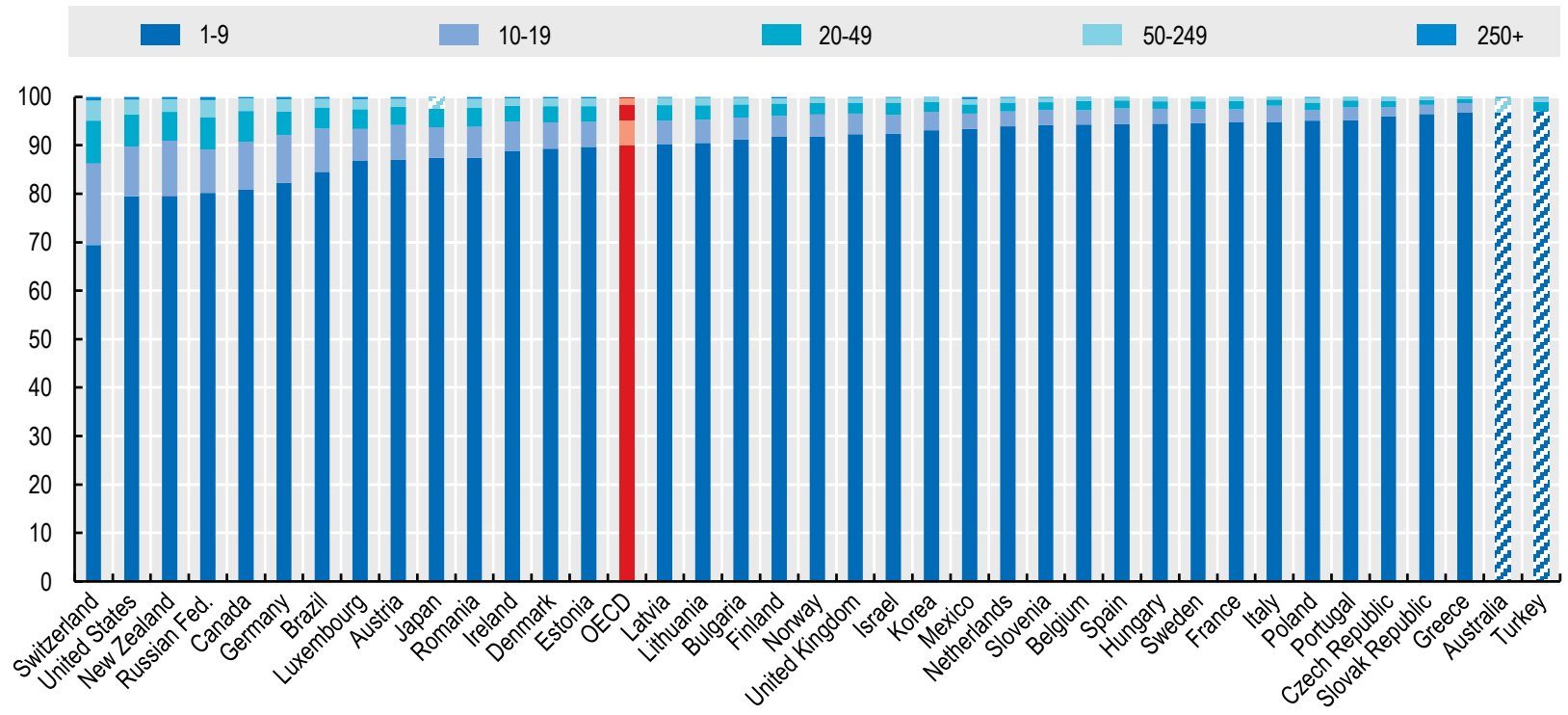

(B) Persons employed by enterprise size in percent of total, 2012 or latest

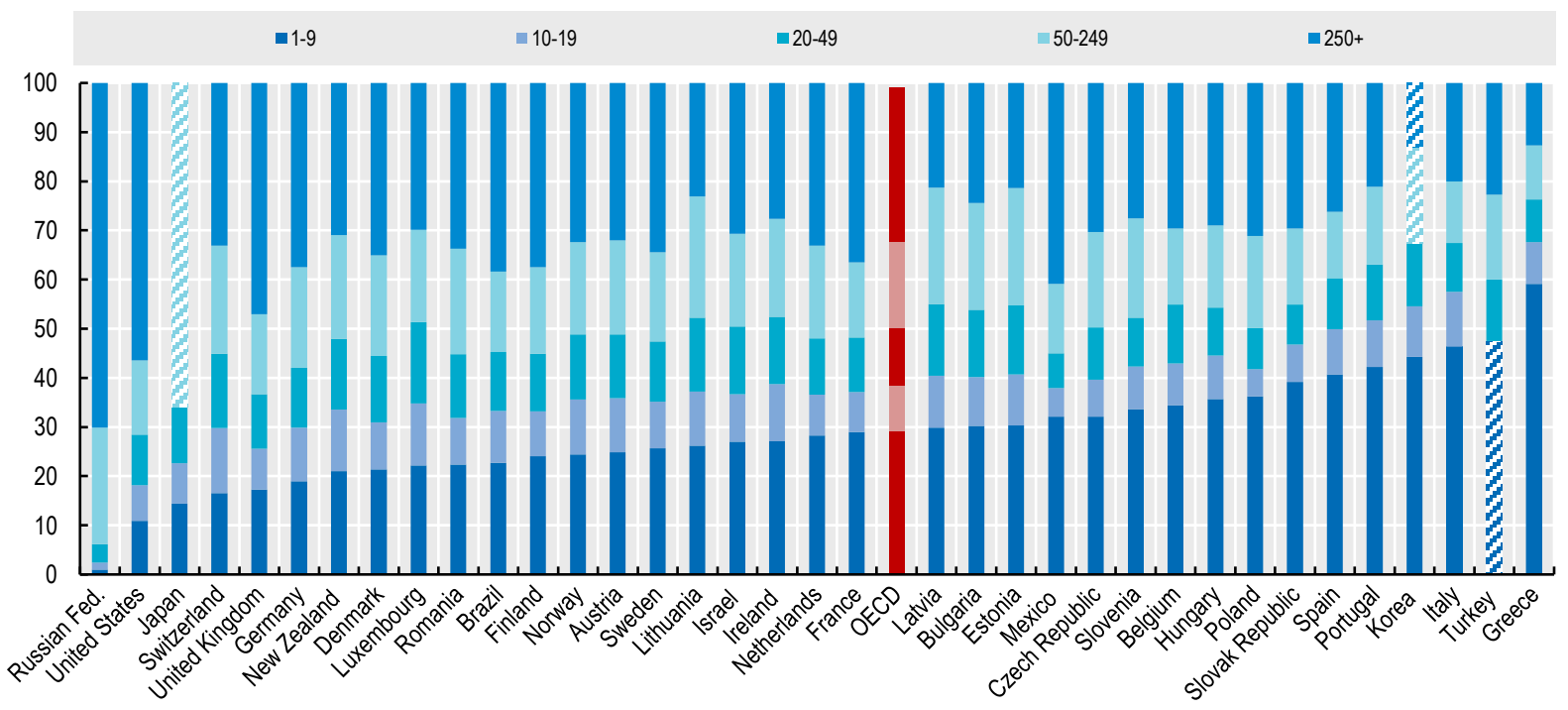

Source: OECD (2015b).

Unlike most countries, where micro-enterprises typically contribute around $10 \%$ to $25 \%$ of value added, in Greece the contribution of micro SMEs exceeds 35\% of value added. Micro enterprises are therefore proving to be one of the most dynamic and important segments of the country's economy (Figure 6) and have the potential to drive growth, employment and innovation. 
Figure 6. Value added by enterprise size, total business economy

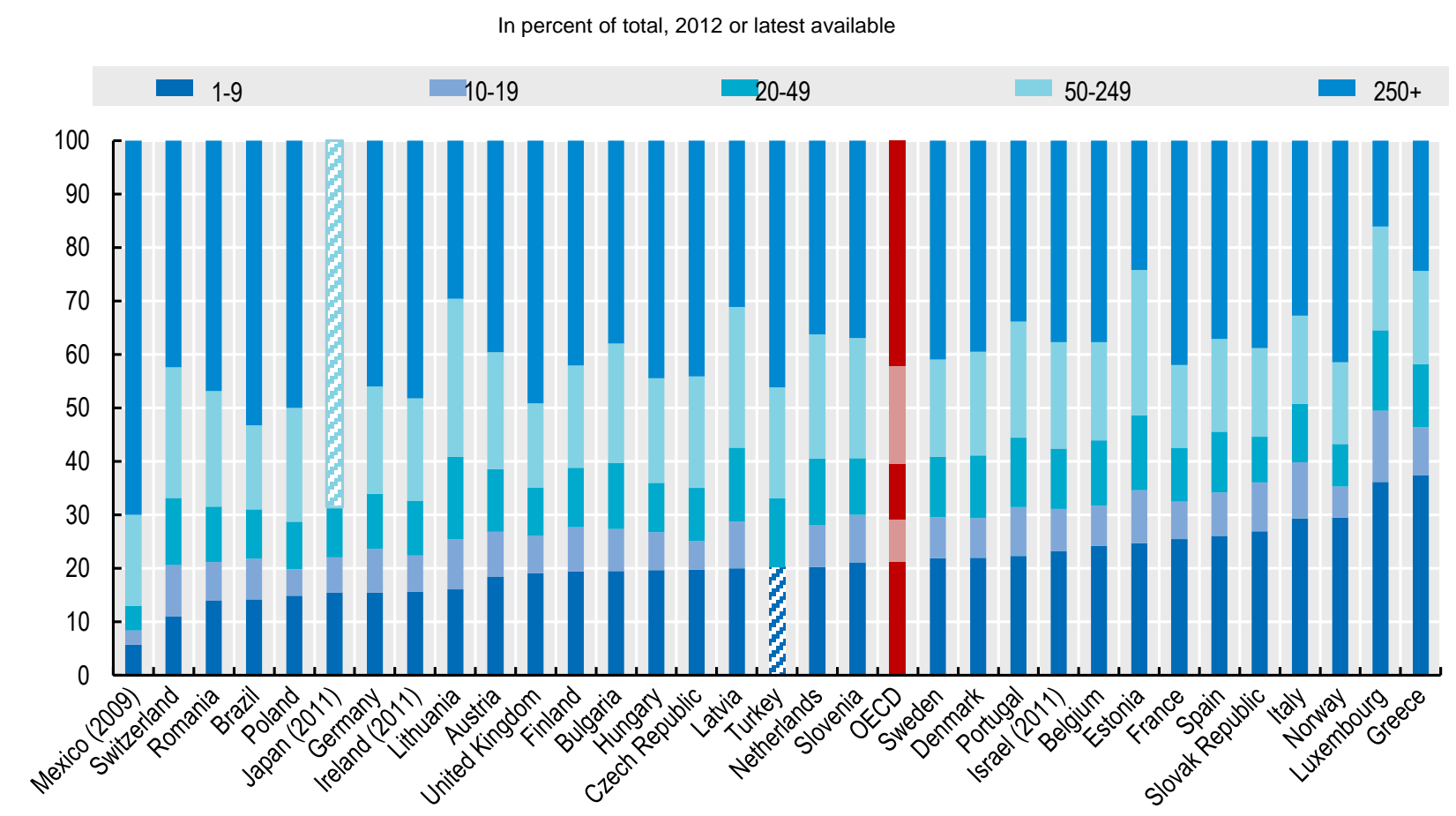

Source: OECD (2015b).

\section{I.3.2. Export activity by domestic SMEs}

The same pattern is found in the distribution of exporting companies by size, with SMEs representing $97 \%$ of exporting companies and micro-enterprises being the dominant SMEs with a $48 \%$ share of exporting SMEs. Despite their prevalence in terms of number of firms, micro enterprises account for just 3.8\% of total exports (Figure 7A), which is nevertheless not too dissimilar from other advanced economies but which at the same time indicates a very low value of exports by those micro enterprises.

Export intensity in Greek SMEs is positively correlated with the size of the firm and over the period 2008-13 exporting activity showed slight increases across all SME sizes, although such increases were insufficient to create a buffer for the decline of the average level of exports (NBG, 2014). Small SMEs with a turnover of up to EUR $0.5 \mathrm{~m}$ have outperformed larger ones in terms of export intensity, defined as the percentage of sales abroad, with a $40 \%$ increase. Although this may partly be attributed to a need to find new markets abroad given the weak domestic demand, it also demonstrates a strong potential for further increase in the export intensity of this dynamic part of the Greek economy. 
Figure 7. Micro SMEs are dominating export activity

(A) Share of number of exporters by enterprise size, in percent of total, as of 2012 or latest available

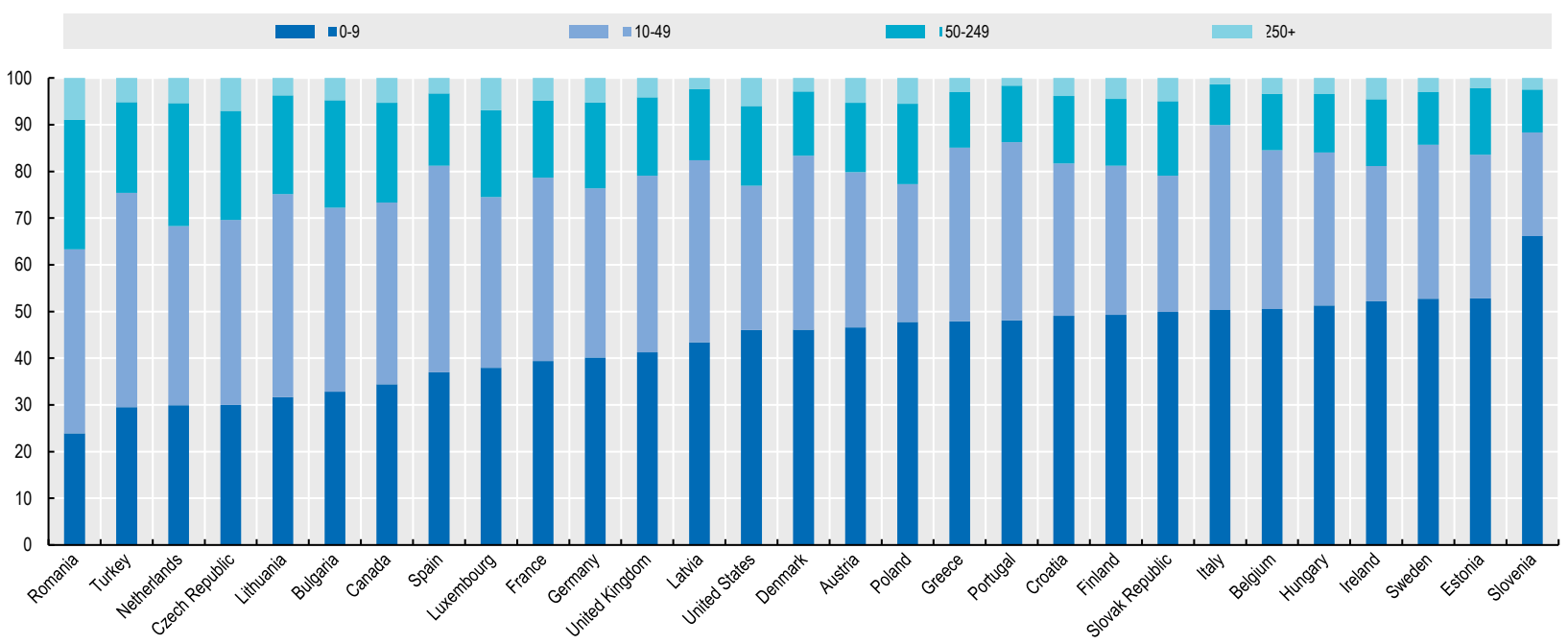

(B) Share of exports by enterprise size, in percent of total, as of 2012 or latest available

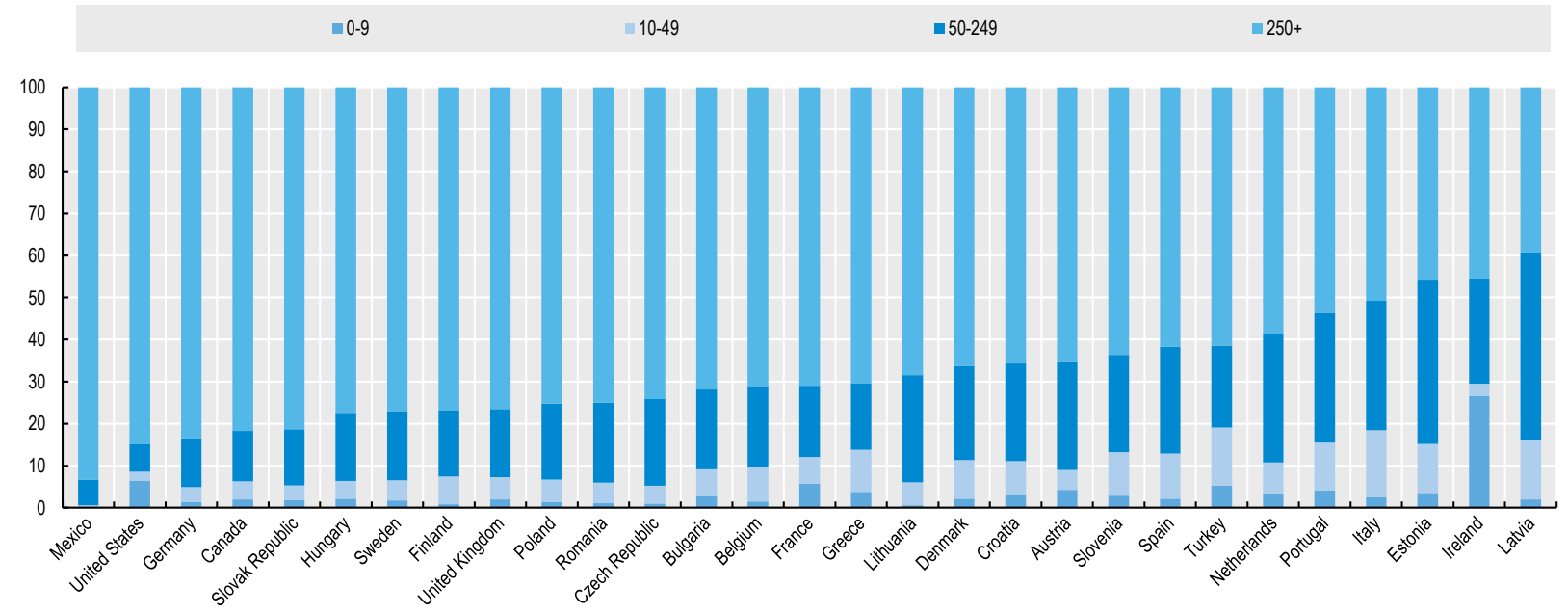

Source: OECD (2015b).

\section{THE BUSINESS CLIMATE: TACKLING IMPEDIMENTS TO THE GREATER CONTRIBUTION OF GREEK SMES TO THE RECOVERY OF EXPORT ACTIVITY}

An economically sound, stable, and business-friendly environment stimulates investment, promotion of entrepreneurship and can boost export activity. A healthy business climate helps using 
productive inputs (land, capital, technology, and skills) more efficiently, underpinning firms' growth and allowing less efficient ones to exit the market in a clear and orderly fashion.

A number of factors impede a greater contribution of Greek SMEs to the recovery of export activity: difficulty in accessing finance, an unfriendly business climate, and low $R \& D$ investment. These issues are analysed below.

\section{1. Alleviating constraints in accessing finance}

Financial systems intermediate between lenders and borrowers and contribute to economic growth by providing liquidity, maturity transformation, lowering transaction costs, and assessing risk. In doing so, they reduce problems of asymmetric information which might lead to credit rationing in a loan market (Stiglitz and Weiss, 1981).

\section{II.1.1. The importance of financing for exporting companies}

Financing of corporates and their ability to access external financing has a direct impact on export activity and performance, as evidenced by both academic literature and market intelligence. Exporting firms are more dependent on external financing compared to non-exporting firms, given the perceived riskiness of exporting activities and the practical difficulties of dealing with payments (Muûls, 2008). Firms that are less financially constrained are found to have more important presence in exporting markets (Manova, 2013). Credit constraints are suggested to prevent firms from getting involved in exporting activities, with financing conditions affecting the firms' decision to enter the exporting markets altogether (Berman et al., 2010).

Empirical evidence on the effects of financing on export of goods in Greece in the last decade confirm the existence of a relationship between financing conditions and exports, suggesting that "firm financing has a positive impact on export performance both in the long and short run, taking into account reverse causality effects" (Bardakas, 2014). This evidences the impact of availability of external financing and of related financing conditions on the ability of SMEs to engage in export activity and contribute to the country's exports.

\section{II.1.2. A growth model based on bank lending and the SME credit crunch}

The vast majority of Greek SMEs faced a persisting credit crunch in the years following the 2008 financial crisis, with the bank credit channel being impaired, due to a large extent to domestic financial system weaknesses. Despite its successful recapitalisation following the losses suffered with the application of the Private Sector Involvement plan, restricted access to interbank lending and heavy reliance on expensive ELA financing for a large part of the crisis period limited the supply of bank lending to the private sector (Bank of Greece, 2013, 2014, and 2015). Heavy deposit losses and liquidity strains added to the problems. Most importantly, asset quality deterioration and the high level of non-performing loans (NPLs) continue to put pressure on Greek banks' balance sheets, with nonperforming exposure (NPE) reaching 40.8\% of their loan portfolios which translates into over EUR 100bn as of Q1 2015 (Bank of Greece, 2015a). ${ }^{1}$

\footnotetext{
${ }^{1}$ NPE includes 90 days past due non-performing loans, as well as loans where there are indications that the borrowers will not manage to fully meet their obligations without the liquidation of relative collateral (Bank of Greece, 2015a).
} 
The highest NPE as of end-2014 was recorded in the corporate loan category, with total NPE standing at EUR 60bn and attributed to a large extent to SME loans. Within the corporate loan portfolio, loans to sole proprietors and very small enterprises recorded the highest NPE ratio (63\%) followed by loans to SMEs (54\%; Bank of Greece, 2015a). Asset quality is expected to further deteriorate given the political and economic uncertainty of 2015, the imposition of bank holidays and capital controls and their impact on the ability and willingness of borrowers' to service their loans. Resolving the NPL problem is of paramount importance for the restoration of liquidity to SMEs and credit expansion to the economy overall (Jemec, 2015).

An insolvency and resolution framework that was, until recently, deemed to be rigid, costly and inefficient has impeded the prompt exit of insolvent SMEs remaining in the system as so-called "zombies" and the efficient debt (but also operational) restructuring of viable SMEs. Restructuring and resolution of SME NPLs is particularly challenging for banks given the small size of the loans, subscale financial reporting and disclosure by the SMEs, potential difficulties in foreclosing on collateral and the high fixed cost of restructuring - especially when compared to the cost of foreclosing on collateral (Bergthaler et al., 2015). The out-of-court restructuring framework for SMEs, introduced in March 2015, can facilitate efficient and less costly rehabilitation of SMEs, while a number of improvements in the insolvency regulation are underway (EC, 2015).

At the same time, bank credit to Greek SMEs remained expensive throughout the crisis, both when compared to larger domestic companies (Figure 8) and vis-à-vis other European country SMEs (Figure 9). A large stock of NPEs may be indirectly pushing interest rates for new loans upwards, as a way for banks to offset unrealised revenues from such NPEs (Bank of Greece, 2015b). It is therefore not surprising that access to finance is regarded as the most important problem of Greek SMEs (ECB, 2015).

Limited demand for lending has further contributed to the credit contraction during the crisis, with SMEs postponing capital investment due to the large decline in turnover, political and economic uncertainty and doubts about the profitability of investment projects that came on the back of restrained domestic demand during six years of persistent recession. In the period October 2014 March 2015, Greek SMEs reported a strong deterioration in turnover in net terms (-18\% of net respondents, down from $-1 \%)$ and a worsening in profitability (-46\% of net respondents; ECB, 2015). A lack of profitability during the crisis has had a negative impact on the ability of companies to access external financing, while at the same time has limited the potential for internal financing through the reinvestment of retained earnings. All that said, Greek SMEs still report the highest net percentages of European SMEs reporting an increase in their need for bank loans (ECB, 2015). But fear of rejection discourages them from applying for a loan, and indeed, Greek SMEs score the highest across the euro area in rejections of loan applications or in loan applications for which only a limited amount was granted, as well as in offers of loans rejected by the SME because of high borrowing costs (ECB, 2015).

Constrained bank lending supply has had a disproportionately large effect on small Greek firms given their heavy reliance on bank lending, with $70.6 \%$ of their total financing representing bank lending compared to the euro area average of $49.1 \%$ for the period 2003-08 (ECB, 2013). The growth model in the years prior to the crisis was based on bank lending, concurrently with the development of the domestic financial institutions and the credit expansion of the system (Bank of Greece, 2014). Heavy reliance on bank lending is consistent with the dominance of micro-enterprises in the total SME population of the country, as small local firms often lack awareness of alternative financing instruments, or skills that can allow them to tap the capital markets or other sources of financing (Nassr and Wehinger, 2015a). 
Scarce information on creditworthiness and performance track record of Greek SMEs decreases transparency in the SME financing market, impeding an informed decision-making by capital holders. Such information is currently available solely to banks by the Tiresias interbank information system, along with a few private databases. The encouragement of ongoing reporting and data-sharing by SMEs would increase transparency and facilitate lending to viable SMEs while also supporting market-based financing. The build-up and sharing of credit ratings in centralised platforms, such as the French FIBEN system, should benefit the entire SME financing market, reduce information asymmetries and the cost of issuing market-based financing instruments (Nassr and Wehinger, 2015b). Their broader accessibility by institutional investors, besides banks, can reduce information asymmetries and subsequently reduce the cost of investing in SMEs by institutional investors.

Figure 8. SME lending and credit conditions in Greece

(A) SME vs. total corporate lending, in EUR million

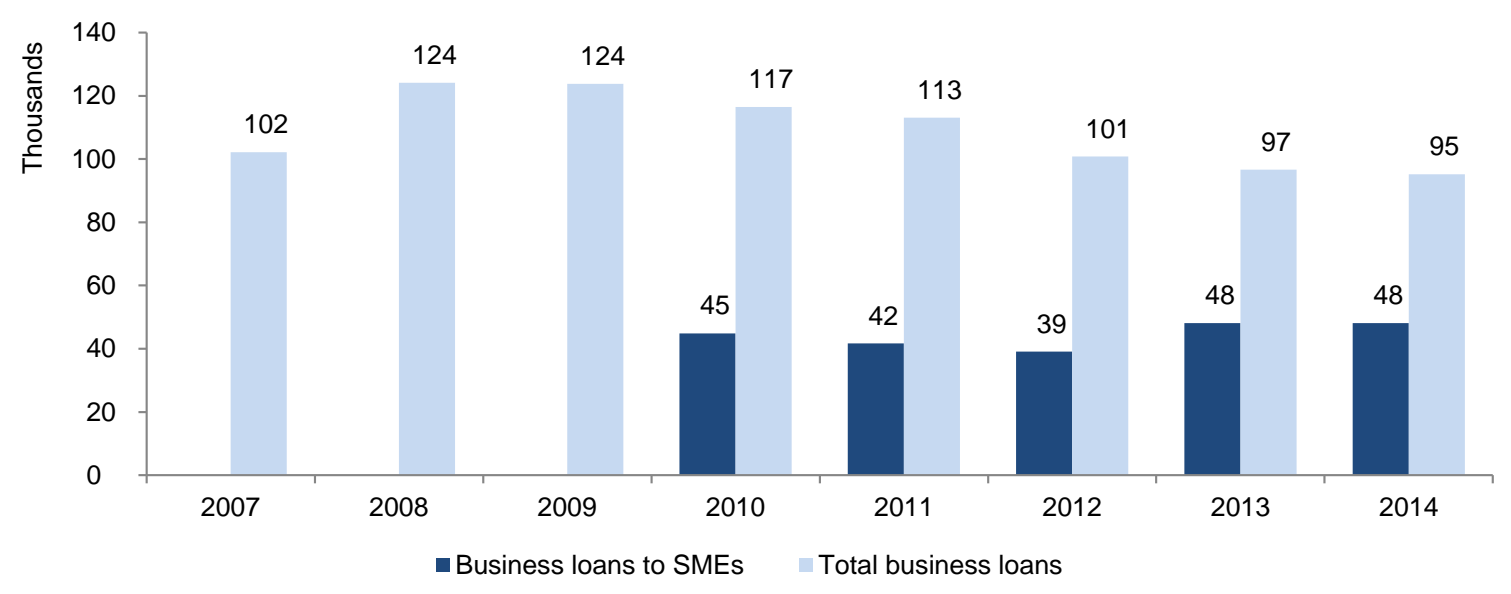

(B) Domestic interest rates on SMEs vs. large corporate loans, in percent

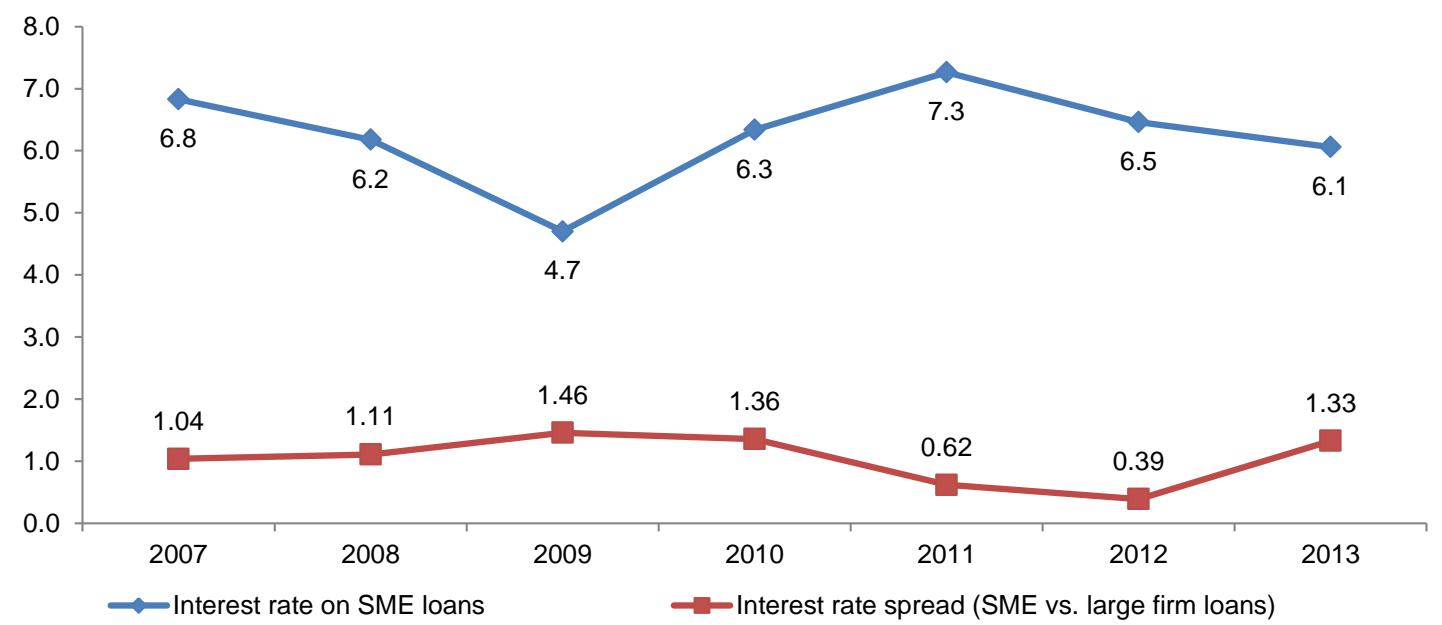

Source: OECD (2015d). 
Figure 9. Credit conditions for Greek SMEs remain tougher than for European peers

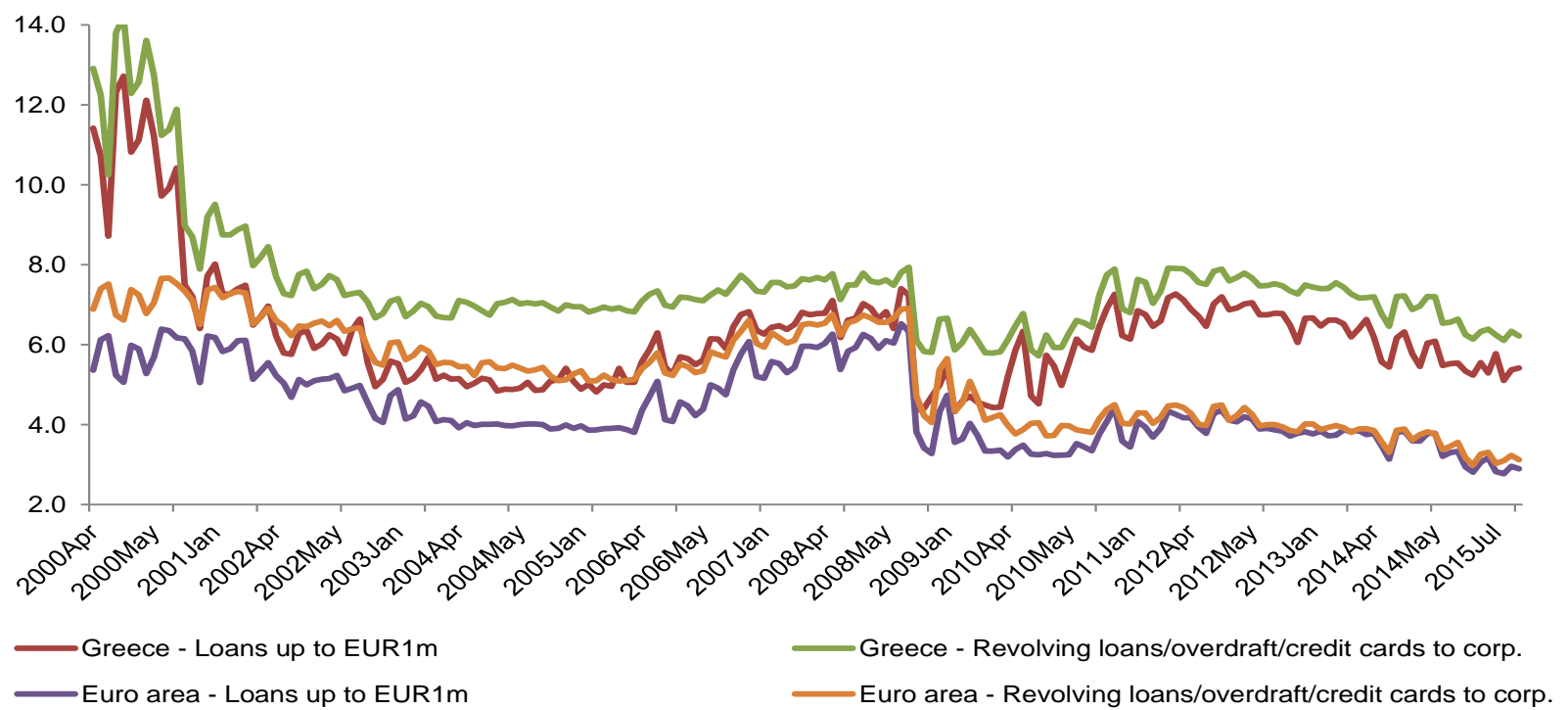

Source: ECB.

Empirical analysis based on micro-data of Greek companies' balance sheets suggest that, while large companies substituted their long-term financing with short-term funding in the years of the crisis, smaller companies faced more hurdles in obtaining external financing and - to the extent possible - tried to replace external financing with internal funding (Dimitropoulou et al., 2014). According to this study, the ability to retain access to financing in the years of the crisis was linked to the size of the company, the profitability, and the decreased operational costs in an environment of restrained credit capacity and reduced risk appetite on the side of the banks. At the same time, the use of internal sources of funding as the sole financing source is not deemed sufficient for the expansion of Greek SMEs (Athanasoglou et al., 2006) which supports the call for other sources of financing to be fostered in the country.

\section{II.1.3. Capital controls weigh on micro and small SMEs}

The recent turmoil surrounding the imposition of capital controls on 29 June 2015 has severely disrupted business and has had a serious economic impact on SMEs that import and export goods. The capital controls had a damaging impact on operating conditions that suffered a dramatic deterioration, and resulted in a significant loss of trade and income. SMEs spent valuable time and money trying to find viable alternatives to honour commitments to their suppliers of imported intermediary products and customers abroad. Often payment in cash is required by foreign suppliers, creating important liquidity constraints for SMEs facing delays in the collection of receivables and a decline in the size or availability of working capital credit line facilities.

The impact of capital controls on SMEs has been particularly severe on the lower end of the SME spectrum, i.e. for micro and small enterprises. A demand-side survey performed by the Institute for Small Enterprises of the Hellenic Confederation of Professionals, Craftsmen and Merchants reflects significant survival problems for SMEs and gloomy expectations for the rest of 2015 (Figure 10B; HCPCM, 2015). Nine out of 10 micro and small SMEs report a massive drop in turnover due to the imposition of capital controls; over 70\% drop for a third of them and an overall weighted average turnover decline of $48 \%$ (Figure 10A). 
Figure 10. Micro and small SMEs reporting survival problems and deteriorating outlook

(A) H1 2015 performance of micro and small SMEs, in percent of respondents

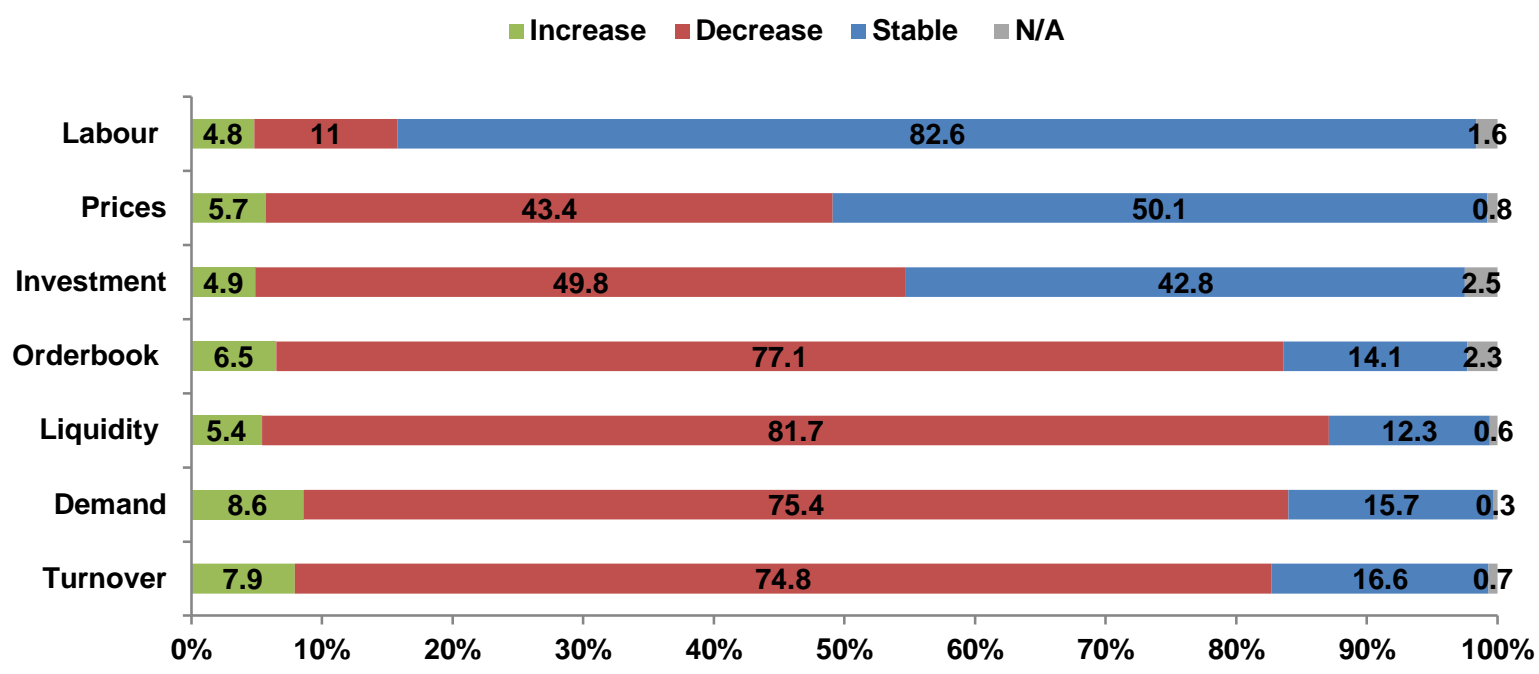

(B) Micro and small SMEs expectations for $\mathrm{H} 22015$, in percent of respondents

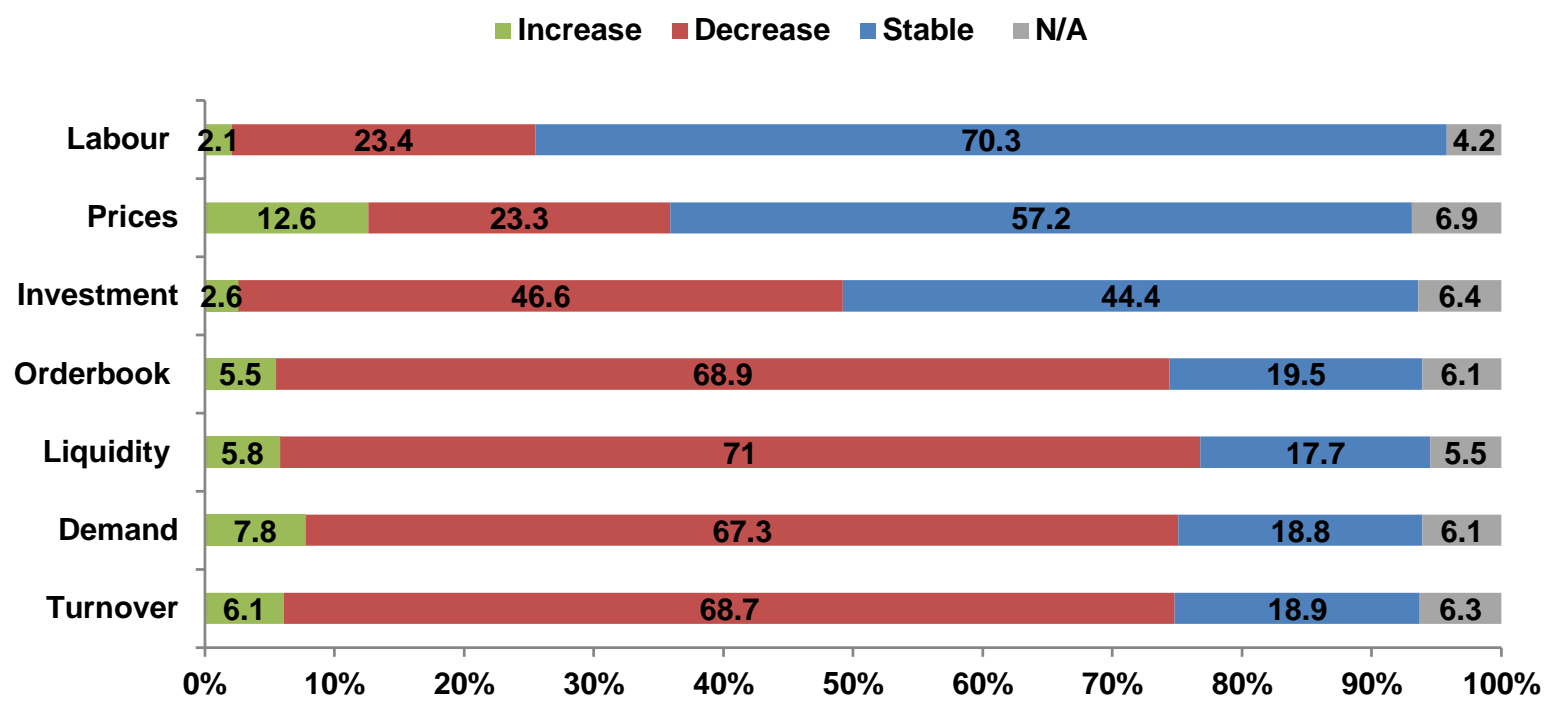

Source: Institute for Small Enterprises of the Hellenic Confederation of Professionals, Craftsmen and Merchants (HCPCM, 2015).

The improving trend in the second half of 2014 seems to have been completely reversed in $\mathrm{H} 1$ 2015, reflecting the wave of uncertainty that succeeded the initial euphoria of early 2015. Due to the capital controls, turnover reportedly declined across the SME sector more broadly, and $46.3 \%$ of SMEs reported as very likely the risk of insolvency (Figure 11) and almost a third of autoentrepreneurs reported that they consider suspending their business. According to the study, the risk of part of them moving into the informal sector of the economy or relocating their business outside the 
country as a way to survive the perceived unfavourable fiscal environment should not be underestimated.

Small businesses were unprepared to handle the impact of capital controls, particularly when it comes to the use of e-banking and electronic funds transfer at point of sale (EFTPOS) payment systems for transactions. According to the HCPCM survey, 7 out of 10 respondents do not have EFTPOS devices for transactions with credit, debit and prepaid cards due to the high purchase cost of those machines, disproportionate to their turnover (HCPCM, 2015). Six out of 10 services companies and 53.3\% of small firms active in trade do not use e-banking, which goes up to $70 \%$ in the case of self-entrepreneurs, with important implications for exporting SMEs.

\section{Figure 11. Effect of capital controls on micro and small SMEs}

(A) Effect of capital controls on turnover, in percent of respondents (H1 2015)

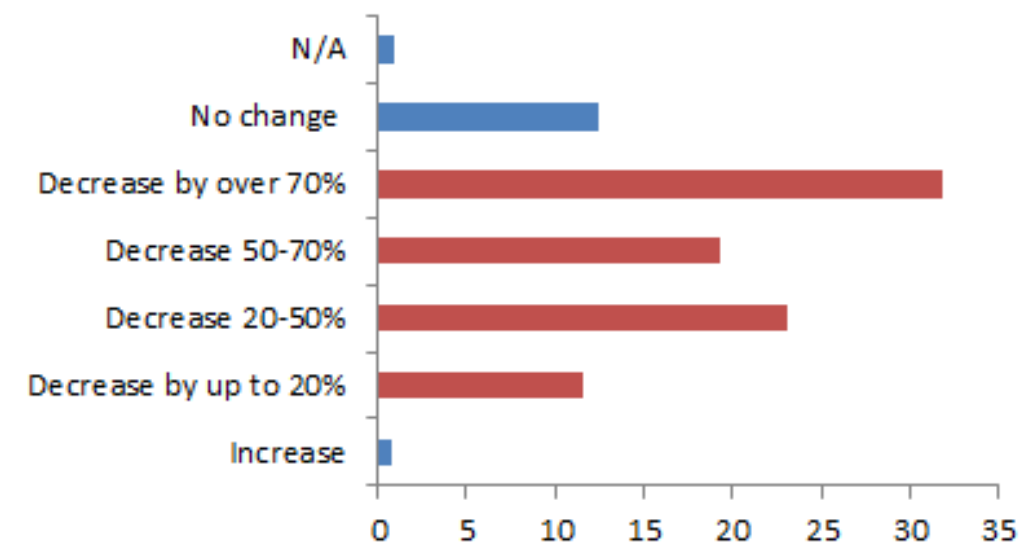

(B) Expectation of insolvency risk, in percent of respondents ( $\mathrm{H} 1$ 2015)

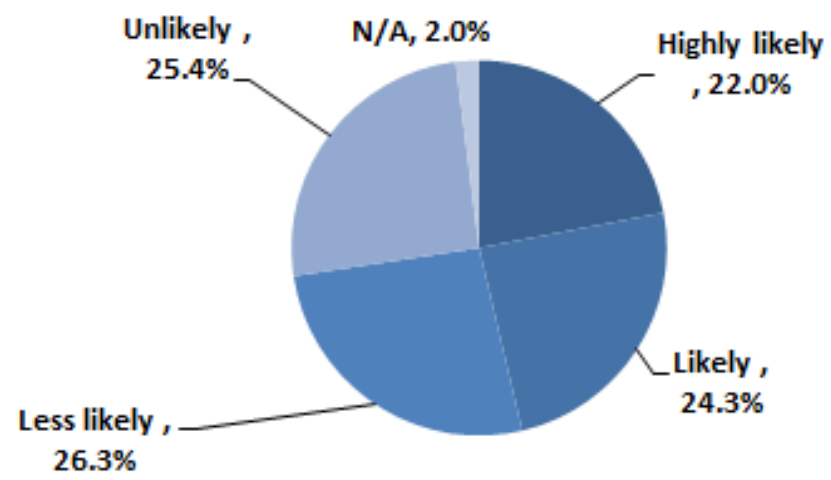

Source: Institute for Small Enterprises of the Hellenic Confederation of Professionals, Craftsmen and Merchants (HCPCM, 2015).

\section{II.1.4. Trade finance and support programmes}

Greek commercial banks offer a number of trade finance products, such as letters of credit, suppliers' guarantees, discount financing, and documentary credits. Export-oriented SMEs also benefit from a number of targeted official programmes, both at local and European level. Domestic commercial banks, in cooperation with the Export Credit Insurance Agency (ECIO) provide export guarantees (on invoice credits) through the 'Outward Orientation' scheme, at a coverage rate of $80 \%$ 
per invoice and up to a total revolving insurance amount of EUR $0.5 \mathrm{~m}$ per exporting company. Under the Trade Finance Facility of the EIB, launched in 2013, the EIB is providing EUR $500 \mathrm{~m}$ in guarantees to foreign banks, covering $85 \%$ of their risk vis-à-vis their Greek counterparts for letters of credit and other trade finance instruments, to mitigate the risks of non-payment or default. The mitigation of risk through the guarantees eases cash collateral constraints and fosters greater comfort and confidence in dealing with Greek issuing banks and SMEs (EIB, 2014). The forthcoming deployment and utilisation of funds provided by the EU National Strategic Reference Framework 2014-20 is expected to assist small businesses to improve their competitiveness and boost their internationalisation.

In addition, lending facilities, guarantee programmes and other public support programmes are offered by the Greek government to local SMEs in cooperation with the European Investment Bank (EIB) Group and the European Commission. However, facilities like the Entrepreneurship Fund, cofinancing direct loans to SMEs, has had a low take-up and loan guarantee schemes have declined by $50 \%$ in 2012 (OECD, 2015c). Liquidity support benefited from guarantees or counter-guarantees and the volume of outstanding guarantees is one of the lowest in Europe, representing 0.1\% of GDP. The guarantee activity further declined in 2014 (Table 1), when guarantees granted represent only $0.0023 \%$ of GDP (Kraemer-Eis et al., 2015).

Table 1. A small number of SMEs has benefited from guarantees and counter-guarantees

Outstanding guarantees and counter-guarantees on SME loan portfolios and resulting average guarantee size in 2014

\begin{tabular}{|c|c|c|c|c|c|c|c|c|c|}
\hline & \multicolumn{3}{|c|}{ Guarantee and counter-guarantee } & \multicolumn{3}{|c|}{ Guarantee activity } & \multicolumn{3}{|c|}{ Counter-guarantee activity } \\
\hline Country & $\begin{array}{l}\text { Volume } \\
\text { [k EUR] }\end{array}$ & Number & $\begin{array}{c}\text { Average } \\
\text { guarantee } \\
\text { size } \\
{[k E U R]}\end{array}$ & $\begin{array}{l}\text { Volume } \\
\text { [k EUR] }\end{array}$ & Number & $\begin{array}{c}\text { Average } \\
\text { guarantee } \\
\text { size } \\
\text { [k EUR] }\end{array}$ & $\begin{array}{l}\text { Volume } \\
\text { [k EUR] }\end{array}$ & Number & $\begin{array}{c}\text { Average } \\
\text { guarantee } \\
\text { size } \\
\text { [k EUR] }\end{array}$ \\
\hline Austria & 828,622 & 5,717 & 144.9 & 828,622 & 5,717 & 144.9 & & & \\
\hline Belgium & 761,332 & 10,488 & 72.6 & 736,573 & 8,942 & 82.4 & 24,759 & 1,546 & 16.0 \\
\hline Bosnia-Herzegovina & 8,072 & 64 & 126.1 & 8,072 & 64 & 126.1 & & & \\
\hline Bulgaria & 108,182 & 1,234 & 87.7 & 107,299 & 1,218 & 88.1 & 883 & 16 & 55.2 \\
\hline Czech Rep. & 645,627 & 7,044 & 91.7 & 645,627 & 7,044 & 91.7 & & & \\
\hline Croatia & 160,734 & 1,416 & 113.5 & 160,734 & 1,416 & 113.5 & & & \\
\hline Estonia & 115,550 & 1,262 & 91.6 & 115,550 & 1,262 & 91.6 & & & \\
\hline France & $18,139,706$ & 742,744 & 24.4 & $17,281,482$ & 692,990 & 24.9 & 858,224 & 49,754 & 17.2 \\
\hline Germany & $5,761,025$ & 48,199 & 119.5 & $5,761,025$ & 48,199 & 119.5 & & & \\
\hline Greece & 245,810 & 7,673 & 32.0 & 245,810 & 7,673 & 32.0 & & & \\
\hline Hungary & $1,358,055$ & 42,276 & 32.1 & $1,318,062$ & 42,223 & 31.2 & 39,993 & 53 & 754.6 \\
\hline Italy & $33,399,702$ & $1,057,470$ & 31.6 & $20,078,000$ & 941,075 & 21.3 & $13,321,702$ & 116,395 & 114.5 \\
\hline Kyrgyz Rep. & 448 & 317 & 1.4 & 448 & 317 & 1.4 & & & \\
\hline Latvia & 98,024 & 454 & 215.9 & 98,024 & 454 & 215.9 & & & \\
\hline Lithuania & 508,376 & 7,150 & 71.1 & 213,616 & 3,739 & 57.1 & 294,760 & 3,411 & 86.4 \\
\hline Luxembourg & 917 & 41 & 22.4 & 917 & 41 & 22.4 & & & \\
\hline Netherlands & $1,911,428$ & 18,301 & 104.4 & $1,911,428$ & 18,301 & 104.4 & & & \\
\hline Poland & $2,009,137$ & 242,273 & 8.3 & $1,925,858$ & 234,857 & 8.2 & 83,279 & 7,416 & 11.2 \\
\hline Portugal & $2,934,500$ & 81,621 & 36.0 & $2,934,500$ & 81,621 & 36.0 & & & \\
\hline Romania & $1,598,484$ & 21,153 & 75.6 & $1,453,011$ & 16,750 & 86.7 & 145,473 & \begin{tabular}{|l|}
4,403 \\
\end{tabular} & 33.0 \\
\hline Russia & 132,993 & 1,601 & 83.1 & 132,993 & 1,601 & 83.1 & & & \\
\hline Spain & $4,350,377$ & 30,903 & 140.8 & $4,350,377$ & 30,903 & 140.8 & & & \\
\hline Slovenia & 230,506 & 2,053 & 112.3 & 230,215 & 2,007 & 114.7 & 291 & 46 & 6.3 \\
\hline Turkey & $5,145,991$ & 318,880 & 16.1 & $5,145,991$ & 318,880 & 16.1 & & & \\
\hline Total & $80,453,598$ & $2,650,334$ & 30.4 & $65,684,233$ & $2,467,294$ & 26.6 & $14,769,364$ & 183,040 & 80.7 \\
\hline
\end{tabular}

Source: AECM (provisional figures), Kraemer-Eis et al. (2015).

The low take-up of some of the existing schemes and the depressed levels of outstanding guarantees on SME loans could be potentially attributed to - besides the aforementioned reasons related to depressed demand and impaired financial transmission of credit - the lack of awareness of 
some of the micro-enterprises about the availability of such schemes, as well as a potential inability to go through the application and implementation process and meet the requirements of such funding to SMEs in order to improve their internationalization is offered via National Strategic Reference Framework (NSRF) targeted subsidies and Hellenic Fund for Entrepreneurship and Development (ETEAN) loans and guarantees. The Guarantee Fund for Greek SMEs and the State Guarantee Facility have been successfully offering guarantee-backed loans through partner banks since 2012 and the uptake of the guarantee programmes is higher than that for direct loans (OECD, 2015d). Nevertheless, only a small number of SMEs have. This highlights the important role of financial education for SMEs that should raise awareness of available schemes, as well as the development of financial skills that should enable them to access and make use of such tools.

\section{II.1.5. A potential role for a development bank in Greece}

A development bank in Greece could systematically organise all the funding opportunities available for Greek SMEs, both from national and international sources. It could streamline the breadth of instruments available and clarify the benefits and costs of each. Even though there are controversies over the benefits of a development bank, a report prepared at the OECD in 2013 shows that in almost every country analysed there is a public financial institution (PFI, usually in the form of a development bank, but also comprising innovation and development agencies) providing funding for viable SMEs and entrepreneurs (Robano, 2013).

Depending on the institutional context, the organisational characteristics of such public financial institutions vary. The main characteristics involve lending using own funding or channelling government or international funds for their activities (in general involving local or regional development objectives). Apart from the funding source, another important characteristic is the way funds are disbursed, whether directly to clients (first-tier banking), or through another financial institution (second-tier banking).

The mandates of PFIs also vary. Intrinsic characteristics of the SME sector (relatively high fixed cost given the small funding volumes desired) make private banks unable and unwilling to lend to viable SME projects. Thus, some sort of public support (centralising and streamlining available resources) is needed for SMEs to gain credit access.

Launching a PFI in Greece could help SMEs to overcome impediments to financing their operations and growth by pooling financial resources from private and public organisations. The centralisation and streamlining of different public agencies and programmes under the umbrella of a single PFI could generate significant benefits, particularly in the case of the currently very fragmented SME programmes and policies in Greece. Acting as an intermediary for the deployment of programmes and funds provided by the EIB Group, a PFI would allow for better dissemination and higher absorption rates, particularly among the smaller SMEs. Such an institution could at the same time promote financial education and capacity building for SMEs, raising awareness of existing programmes and building the skills necessary for SMEs to make use of available facilities, thus increasing take-up rates. The establishment of such a PFI would also facilitate and maximise absorption of NSFR funds and other European structural funds and programmes (Investment Plan for Europe or "Juncker Plan", EIB Group funds). Appropriate planning and creation of programmes suitable for the country's SMEs, communication of the initiatives and the provision of training combined with direct financial support or guarantees could increase effectiveness and overall take-up of official sector support, as noted by Bruhn and Zia (2011).

The Institution for Growth (IfG) created in December 2013 could be seen as a first step to the creation of such PFI. The IfG SME Debt-Sub-Fund was established in May 2014 as the first of three 
sub-funds foreseen for this institution (EC, 2014). An initial fund of EUR 200m from the Hellenic Republic and the German KfW was coined to provide liquidity for SMEs through the refinancing of existing loans or working capital lines. The Greek government has committed to invest EUR 350m to the Fund over a 3 year period with funds from the Public Investment Programme and EU's Structural Funds (ERDF) through ETEAN (OECD, 2015d). The first two contracts with domestic retail banks were signed in December 2014 and by May 2015 almost 300 contracts of ca. EUR 80m were signed and ca. EUR 65m have been disbursed to cover the approved loans (OECD, 2015d). A second stage of the IfG, targeting equity investment, is currently being planned.

The mandate of the IfG could be expanded along the lines of a typical PFI, centralising and streamlining agencies and programmes for SMEs. Its activities could also include the provision of non-financial services (such as financial education, capacity building, and raising awareness about best-suited financial instruments) to exporting SMEs with viable projects, with a view to increase their uptake of available support schemes. The institution could also be in charge of ensuring coherence across different private and government agencies fostering export financing and SME financing in general.

The OECD has proposed a set of guidelines for good practices fostering finance for entrepreneurship (Robano, 2013). Following Crespi, Fernández-Arias and Stein (2014), the priority is to identify the market failure that calls for public action. Then, an evaluation of an ideal policy action to correct for the market failure, and finally, an assessment of whether the public agency in charge would have the institutional capacity to implement the policy action needed to correct for the market failure. A summary of institutional and financial good practices are summarised below (Box 1).

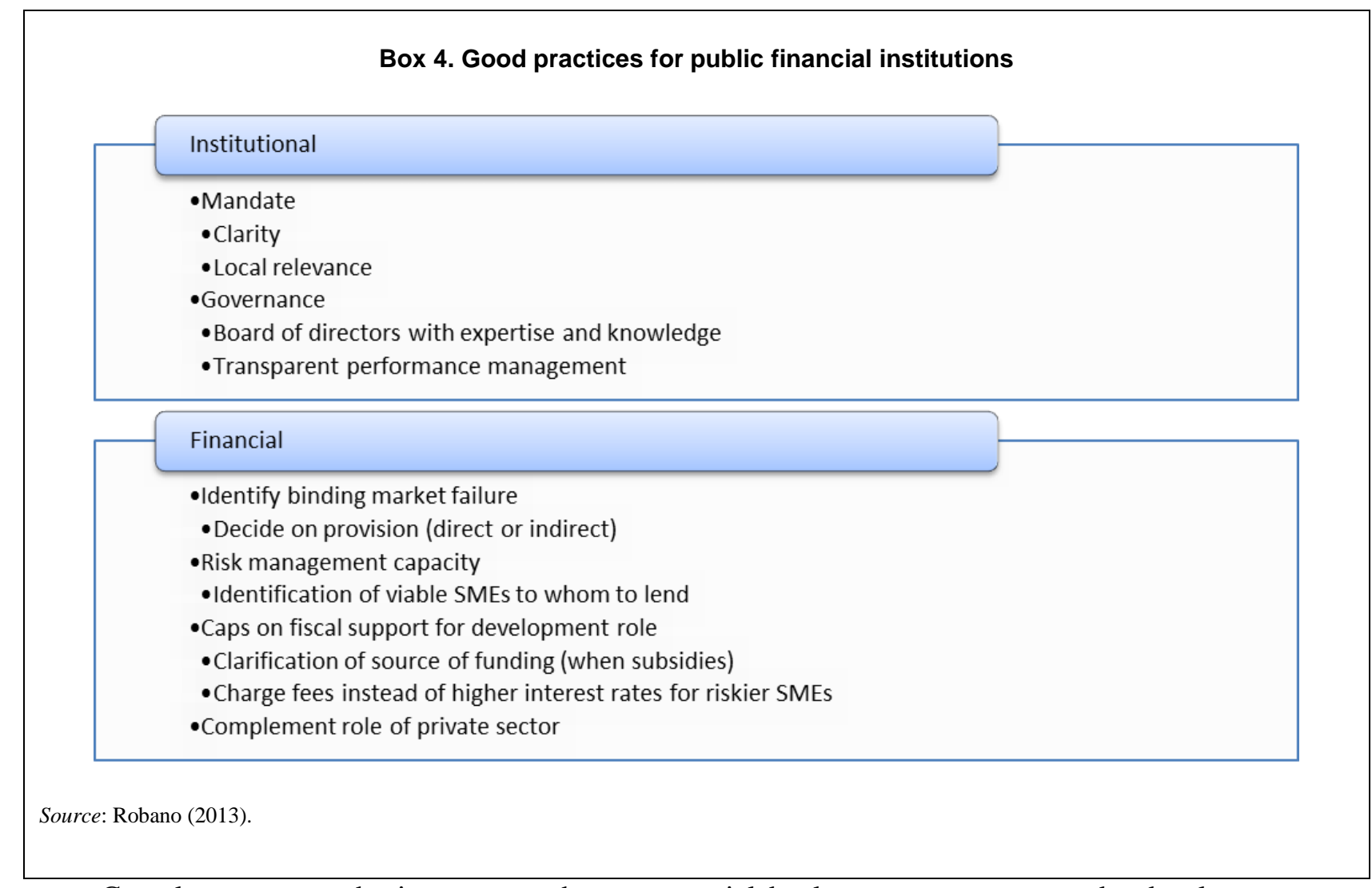

Complementary to the instruments that commercial banks use to promote trade, development banks can provide export credit and insurance, as well as factoring for receivables. Regional and local 
development banks had an important role in supporting both SMEs and commercial banks during the 2008-09 crisis, with the purpose of stabilising commercial trade (OECD, 2009; European Association of Public Banks, 2010; Olloqui and Palma-Arancibia, 2012).

\section{II.1.6. Developing equity financing and links between VC and university research}

The share of SME financing provided through equity markets is Greece is currently very small, particularly when it comes to risk financing. Venture capital investment has been historically underdeveloped in Greece, but the near inexistence of such funding is particularly relevant and crucial at the current juncture. Total venture capital investment for 2014 reached USD $0.26 \mathrm{~m}$, by far the lowest in OECD countries (Figure 12; OECD, 2015b). A number of public support programmes do exist in the country, such as the New Economy Development Fund S.A. (TANEO) and the JEREMIE initiative public-private co-financing funds, catalysing private investor participation in venture capital financing (OECD, 2015c), but fail to reach a larger scale.

The importance of equity financing has been to a large extent underreported and undervalued by Greek SMEs given a growth model based on credit expansion and the lack of well-developed risk capital financing (private equity, especially venture capital and angel investors). Similarly to other European countries, it could be argued that special bank loan structures carrying higher interest rates have been used as a means to close an equity financing gap by providing de facto equity in de jure loan structures (Nassr and Wehinger, 2015b). Given that the amount of equity held by a company defines, inter alia, its debt capacity and thus the provision of debt financing and the overall health of the financing structure, the development of equity financing should not be overlooked.

Figure 12. Greece a laggard in venture capital investment

In percent of GDP, 2014 or latest available year

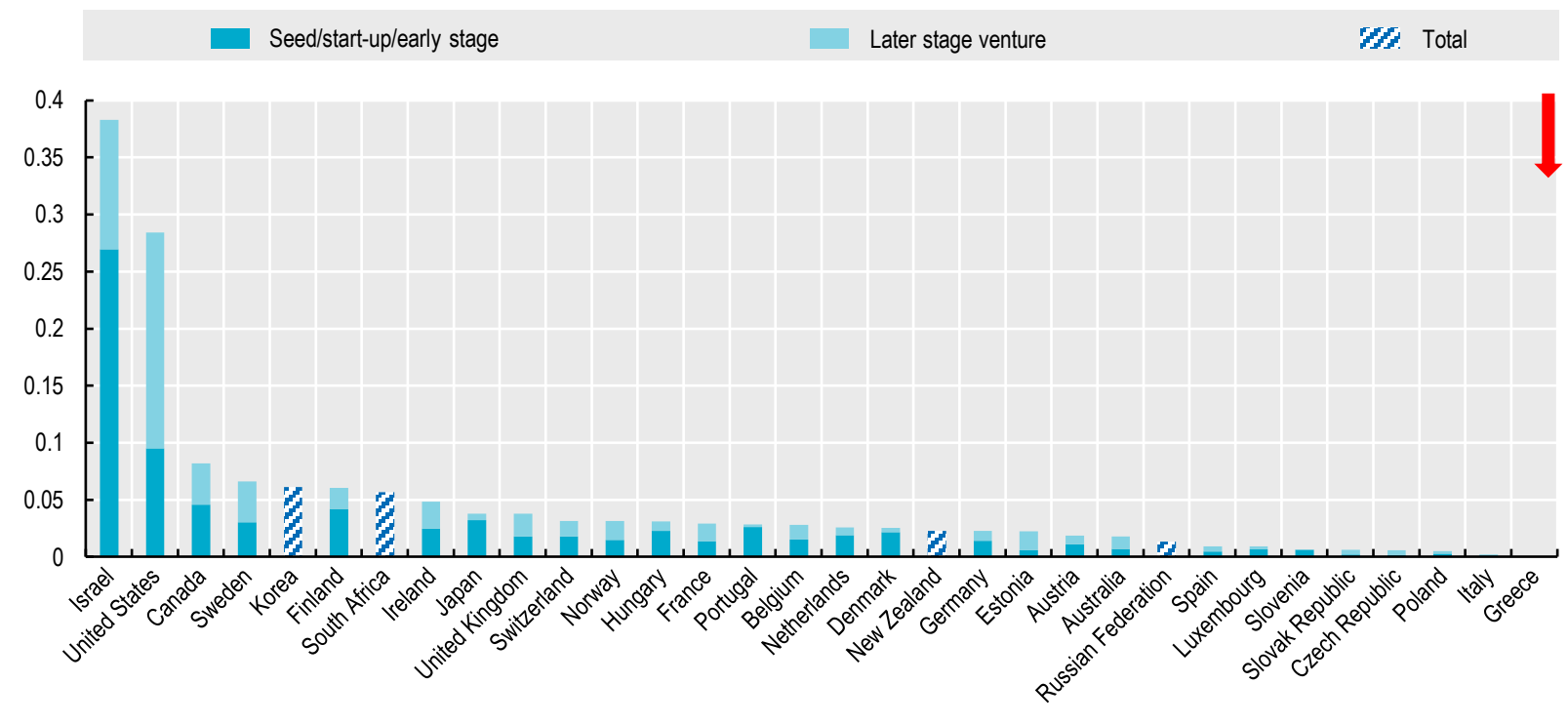

Source: OECD (2015b).

Venture capital is a particularly important source for the provision of risk finance for start-ups and small companies with innovative products or services and untested business models. The absence of tangible (if at all) collateral or positive cash flows that can be pledged for loan financing is usually an extra impediment to debt financing that can be overcome by venture capital funding, although 
arguably debt and equity financing correspond to different risks and should be seen in a rather complementary way along a company's life cycle.

The underdeveloped venture capital financing in Greece could be driven by risk aversion of venture capitalists given the prevailing macroeconomic situation and, most importantly, the uncertain economic and political environment. Exit markets, bankruptcy regulations, labour market restrictions and other framework conditions play an important role in seed and early stage financing (Wilson and Silva, 2013). Regulatory and administrative barriers to venture capital investment can affect institutional investors in the same way that these affect entrepreneurs (see Section III). An uncertain and unstable tax and legal environment further impedes business angels and venture capital investors, and anecdotal evidence suggests that a number of innovative young firms relocate to other jurisdictions in order to secure venture capital backing and a friendlier business environment.

The importance of social capital and development of human capital is critical to success in earlystage financing, and networks are suggested to play a key role in the growth of small companies beyond national borders (Wilson and Silva, 2013). The importance of networks is also evidenced in the case of business angel investments, with angel investors becoming more active and visible through their participation in syndicates and networks (OECD, 2011). ${ }^{2}$

The creation of a venture capital ecosystem with important direct links to university research and innovation could be a way to boost entrepreneurship and promote the creation of high value added products and innovative SMEs. As discussed below (in section III.1), such links are currently missing. Greece scores relatively high in terms of $\mathrm{R} \& \mathrm{D}$ and innovation, as well as academic co-authoring (OECD, 2014d), but lacks the ecosystem through which research can be translated into innovative products or services and which can be transformed into fast-growing start-ups and SMEs. A higher contribution of knowledge-based capital $(\mathrm{KBC})$ products in the total exports of the country by innovative SMEs in products or services could allow for a higher value added component of Greek exports and a better integration in GVCs.

\section{II.1.7. Securitisation and capital market financing}

Simple, transparent and standardised securitisation ${ }^{3}$ of SME loans (and other liabilities such as leasing) can be seen as a market-based shortcut to indirectly foster SME financing, 'unclogging' the bank lending channel by transferring SME credit risk partially from originators to investors and achieving capital relief. ${ }^{4}$ Securitisation creates headroom in banks' balance sheets and allows them to further on-lend to small, heterogeneous and mostly local SMEs (Nassr and Wehinger, 2015a). This instrument can be even more relevant in the case of Greece in the medium term for as long as it takes for alternative financing instruments to develop, and also given the traditionally heavy reliance of local SMEs on bank financing.

\footnotetext{
${ }^{2}$ On a different (smaller) scale, the size of the network is important for the success of online platforms (peer-topeer lending and crowdfunding activities).

3 In line with the recent European Commission Securitisation initiative, see http://ec.europa.eu/finance/securities/securitisation/index_en.htm

${ }^{4}$ Covered bonds are instruments with similar characteristics to securitisation but do not provide the possibility of risk transfer and regulatory relief offered by securitisation, while they involve asset encumbrance concerns.
} 
Securitisation of SME loan portfolios, which could be undertaken after the resolution of legacy non-performing loans, will allow banks to continue to originate the bulk of small loans, leveraging on their expertise, infrastructure, local presence and relationships, while keeping some "skin in the game" to ensure robust origination practices are followed (Nassr and Wehinger, 2015a). The experience of systemic banks with securitisation techniques, having executed several shipping portfolio securitisation transactions, as well as official sector support ${ }^{5}$ can allow for smooth execution of such transactions. SME securitisation accounts for almost a third of total issuance, although in a low base of issuance (Figure 13).

Despite an increase in total securitisation issuance in the past years, only a small minority of transactions was actually placed with investors (Figure 14), with the majority of deals being retained for repo funding with the ECB throughout the period when such collateral was eligible for central bank repo refinancing. Although allowing the posting of SME securitisation as collateral with the ECB was undoubtedly beneficial given the collapse of the interbank market, some industry players believe that such policy had a detrimental effect to the revitalisation of the 'real' securitisation market. Retention rates are especially high for SME securitisation across Europe, as compared to securitisation more broadly (Nassr and Wehinger, 2015a).

The key benefits of securitisation were not achieved through such funding operations, as they provided no capital relief and therefore did not allow for further on-lending through redeployment of funds to the real economy and to the SME sector. At the same time, the absence of a capital relief cannot assist in the deleveraging effort of the banks. ${ }^{6}$ The fostering of an active SME securitisation market should therefore be steered towards issuance that is placed with investors in the market, rather than retained for funding purposes.

Limited access to alternative sources of direct SME financing means that the current absence of credit cannot be easily or immediately replaced by other sources of finance. Capital market financing conditions remained particularly difficult for Greek SMEs with regard to the issuance of equity or debt due to valuation pressures on Greek corporates. Such pressures are not only due to the recessionary macroeconomic conditions but come also as a result of the negative country outlook and the trickling down of country credit rating downgrades to corporate downgrades.

The loss of trust that came as a consequence of the uncertain macroeconomic and political environment has also contributed to the inability of Greek companies to tap the capital markets (Bank of Greece, 2015a). Interestingly, the only corporates to have successfully issued corporate bonds in the capital markets since 2012 have been export-oriented companies or companies with important share of export activity (Titan, Fage, OTE, Hellenic Petroleum and Frigoglass). Although these are larger corporates, this is a clear indication that, when the window opens, export-oriented companies will be the first ones to enjoy capital market financing and secure the involvement and buy-in by international investors.

\footnotetext{
${ }^{5}$ As in the example of the first SME loan securitisation transaction in Greece brought to the market by Eurobank and supported by the EIB Group through the participation of EIF.

${ }^{6}$ It should be well noted, however, that the purpose of these official programmes is to enhance the functioning of the monetary policy transmission mechanism by supporting lending to the real economy and not to support the revival of any particular market.
} 


\section{Figure 13. Outstanding Greek securitisation by collateral, as of Q4 2014}

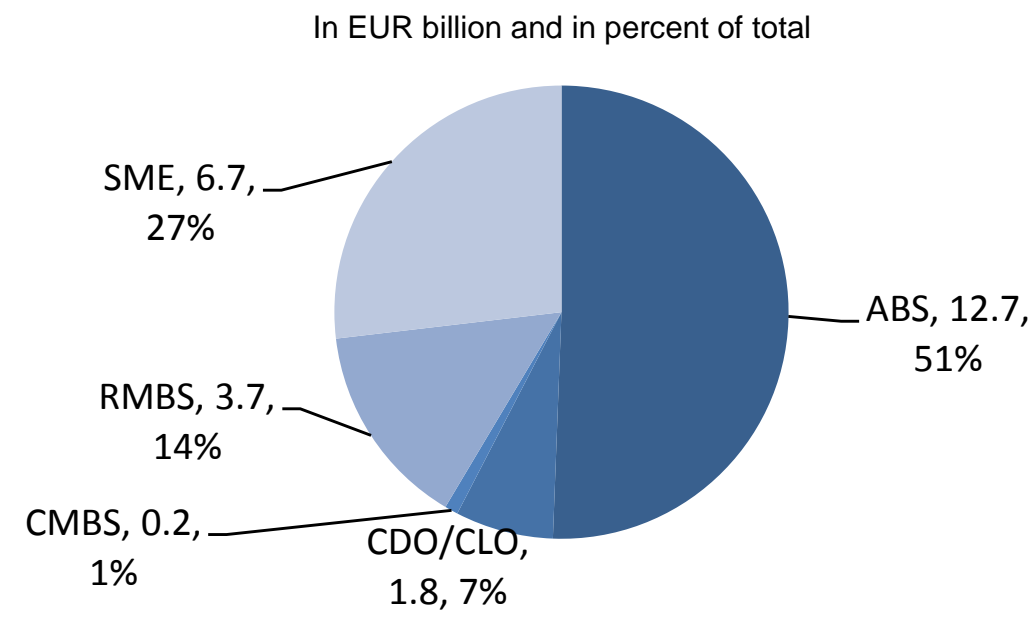

Source: Thomson Reuters, SIFMA (2015).

Figure 14. All post-crisis Greek securitisation issuance was retained

In EUR mn (I.h.s.) and percent of total (r.h.s.)

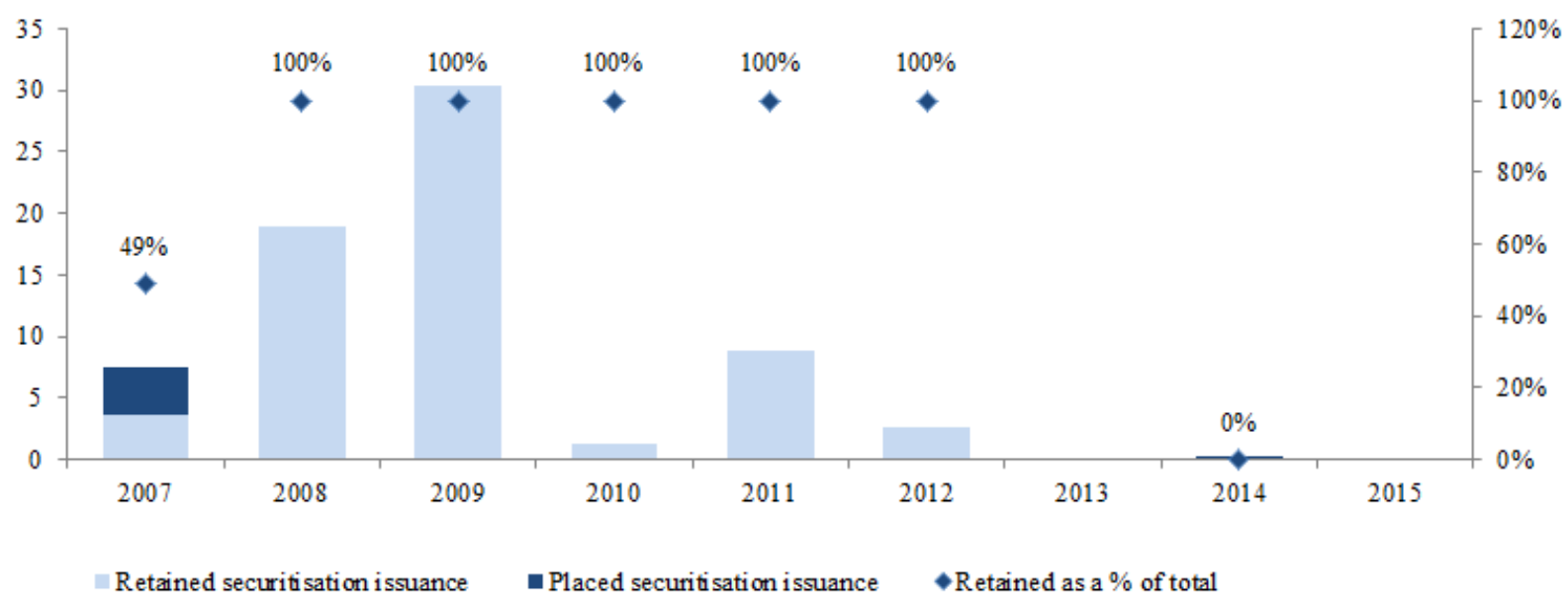

Note: There was no securitisation issuance in 2013, and in 2014 there was only a single small transaction (under EUR500m) which was placed with investors (Alpha Bank).

Source: Thomson Reuters, SIFMA (2015).

Improving capital market financing for SMEs should include fostering the development of SME bonds, private placements, and listed equities. ${ }^{7}$ The establishment of SME-specific trading platforms with proportionate costs and requirements for SMEs can facilitate the use of market based financing by SMEs, rendering the SME asset class reachable and investable by institutional investors (Nassr and

\footnotetext{
${ }^{7}$ See Nassr and Wehinger (2015a,b) for a discussion of alternative SME debt financing instruments beyond securitisation and public equity for SMEs, and OECD (2015f) for a more general overview of a wide range of non-bank financing instruments.
} 
Wehinger, 2015b). The Athens Exchange has established EN.A Alternative Market ${ }^{8}$, a multilateral trading facility (non-regulated market) where SMEs can issue equity or debt (bonds) with easier, faster and more affordable trading admission requirements. Although currently investor appetite for Greek risk is deemed low, once political and economic stability returns, such a marketplace can serve as an important platform for the fostering of alternative financing for SMEs.

With the infrastructure in place, SMEs remain to be induced to use market-based finance. Bridging the educational gap that many SMEs are facing, raising their awareness of capital market financing options available in the country and equipping them with the skills required to tap the public markets, SME participation in these markets can be fostered (Nassr and Wehinger, 2015b). The creation of an ecosystem around those markets and instruments can support small-sized transactions and accompany SMEs from their IPO to follow-on issuance and in the aftermarket.

Capital market financing should however, be seen as complementary to, rather than a substitute for, banking lending. Indeed, the different forms of SME financing are not necessarily exclusive: equity financing should go "hand in hand" with debt financing and the existence of both wellfunctioning equity and debt markets are required for efficient and effective SME financing and for the build-up of balanced and healthy balance sheets throughout the life cycle of an SME (OECD, 2015e). Strong links and interconnections exist between venture capital and other private equity looking for exits on one side, and public equity markets for SMEs on the other. Therefore, policies to improve SME financing should take into account all different areas of SME financing, and aim at developing an appropriate 'ecosystem' to support market-based finance more generally.

\section{II.1.8. Crowdfunding and Microfinance}

Besides internal financing (working capital, retained earnings), and "traditional" external financing (bank lending, corporate bonds, equity offerings etc.) the recent introduction of peer to peer lending and crowdfunding could have a role to play in the financing of Greek innovative SMEs. Crowdfunding can be understood as a way to monetise social media activities, as it usually involves an interaction where the investors have not only financial but perhaps also social and local development objectives. Crowdfunding could help to boost SMEs or projects in targeted areas, and even though the size of the crowdfunding market is still very small to be relevant, it has significant growth potential. In 2013, equity crowdfunding was estimated to be between EUR 50-100 million, about $0.3 \%$ of the overall initial public offering market in Europe, a very small share; and also small compared to EUR 1800 million invested in start-up activities (OECD, 2015k,1). Global crowdfunding activities - which include donations and rewards-based campaigns - are estimated to account for EUR 34400 million in 2015 (Massolution, 2015).

The act4Greece crowdfunding platform launched by National Bank of Greece in early 2016 is a pioneering crowdfunding programme in Greece, aiming at the financial support and promotion of social and developmental actions supported by National Bank of Greece in strategic cooperation with national and international organisations and foundations. ${ }^{9}$ Although funds raised during the first stage of the programme are targeted to support social action (school meals, medical care, education), the establishment of a crowdfunding tool at national level and the infrastructure created around it are

\footnotetext{
${ }^{8}$ www.helex.gr/web/guest/listing-alternative-market

9 At its lauch, the programme is supported by the Alexandros S. Onassis Foundation, the John S. Latsis Foundation, the Bodossaki Foundation, the Hellenic National Commission for UNESCO and the Hellenic Network for Corporate Social Responsibility.
} 
preparing the ground for broader use of the instrument to support entrepreneurship. The programme is expected to be expanded to businesses as soon as the institutional framework is in place, enabling the platform to be used as a business financing tool (NBG, 2016).

For micro SMEs, microfinance, too, could be seen as a way to finance short-term needs or smallscale projects. EIB Group initiatives in Europe, aiming to enhance the capacity of eligible intermediaries to provide micro-credits and guarantees on micro-credits, can support such a market (e,g. Progress Microfinance) - with potentially important social benefits (e.g. helping the unemployed to become entrepreneurs and facilitate start-ups with high growth potential).

\section{II.2. Addressing regulatory barriers}

Predictability, clarity, and transparency of the 'rules of the game' are essential background conditions to ensure private sector development and its contribution to sustainable and sustained growth. Both the public and the private sector have to have appropriate defined roles and responsibilities in order to strengthen the business environment. Improving the business climate requires alleviating unnecessary regulatory burdens, examining restrictions to trade in services and in product markets, assessing the existence of barriers to entrepreneurship, tackling administrative opacity, and having effective dispute resolution mechanisms in place. These issues are analysed below.

While regulation intends to correct for market failures and information asymmetries, improving the balance between the objectives of different stakeholders, regulatory barriers can be a burden on businesses, including SMEs. Unnecessary regulation and a heavy administrative burden linked to the creation of a company can raise the costs of entering a market overall. Such costs are relatively higher for SMEs given their size and limited resources, because most of regulation entails a fixed cost (the load being more burdensome on businesses dealing with small volumes). SMEs usually also face relatively higher compliance costs and may be less efficient in dealing with regulatory requirements as they might not have enough dedicated personnel and other resources to deal with these tasks. In smaller companies the entrepreneur might be the one reallocating time away from business operations in order to deal with regulation (EC, 2007; Frontier Economics, 2012:10).

Addressing administrative barriers (such as bureaucratic obstacles and costly red tape) will allow SMEs to engage more in export activity and get more involved in GVCs. Interestingly, according to a recent study, downsizing public sector activities can boost export activity (Tagkalakis, 2014). In a 2012 survey conducted by the European Commission, the top ten most burdensome administrative acts for SMEs were identified. The top dimensions identified by SMEs as most burdensome were: dealing with taxation, with product safety standards, and with employment legislation (see Box 2).

\section{II.2.1. Restrictions on trade in services}

An appropriate regulatory framework brings clarity, transparency, and certainty to investors, consumers and other stakeholders. However, inefficient regulation might unduly lower investors' benefits, and might impede consumers benefitting from lower prices and a broader basket of goods and services brought in by international trade.

The OECD calculates an index of restrictiveness in trade that serves to identify which policies and regulatory measures act as a barrier to trade and render further insertion in global value chains more difficult. 


\section{Box 5. Results of the public consultation on the top 10 most burdensome legislative acts for SMEs}

The EC launched an on-line questionnaire from October to December 2012 to identify the main regulatory burdens for SMEs through public consultation. The TOP10 public consultation received over 1000 responses, 779 from enterprises (628 of them were European SMEs and 118 responses were from SMEs located outside the EU; the remaining answers were from self-employed and micro enterprises [1-9 employees]); 154 from organisations representing the interests of enterprises, and 67 from other stakeholders.

One of the more burdensome areas for SMEs in the EU was found to be taxation: dealing with VAT covered 6\% of all answers, followed by dealing with direct taxes (income, capital, double taxation), which obtained $4 \%$ of all replies from SMEs. Other indirect taxes obtained $2 \%$ of the answers. These three taxation categories add up to $12 \%$, the same as employment and social affairs regulations (Figure 15). Summing up all different regulations regarding product safety, this category obtained the majority of answers (31\%). The category of product safety comprises labelling obligations; demonstrating conformity in the absence of a harmonised standard; information obligations (language requirements, instructions for use/safety); use of standards; controls / inspections; conformity assessment procedures; EU declaration of conformity; CE marking rules; conformity assessment involving a conformity assessment body; and traceability obligations.

Figure 15. Top 10 most burdensome legislative acts for SMEs

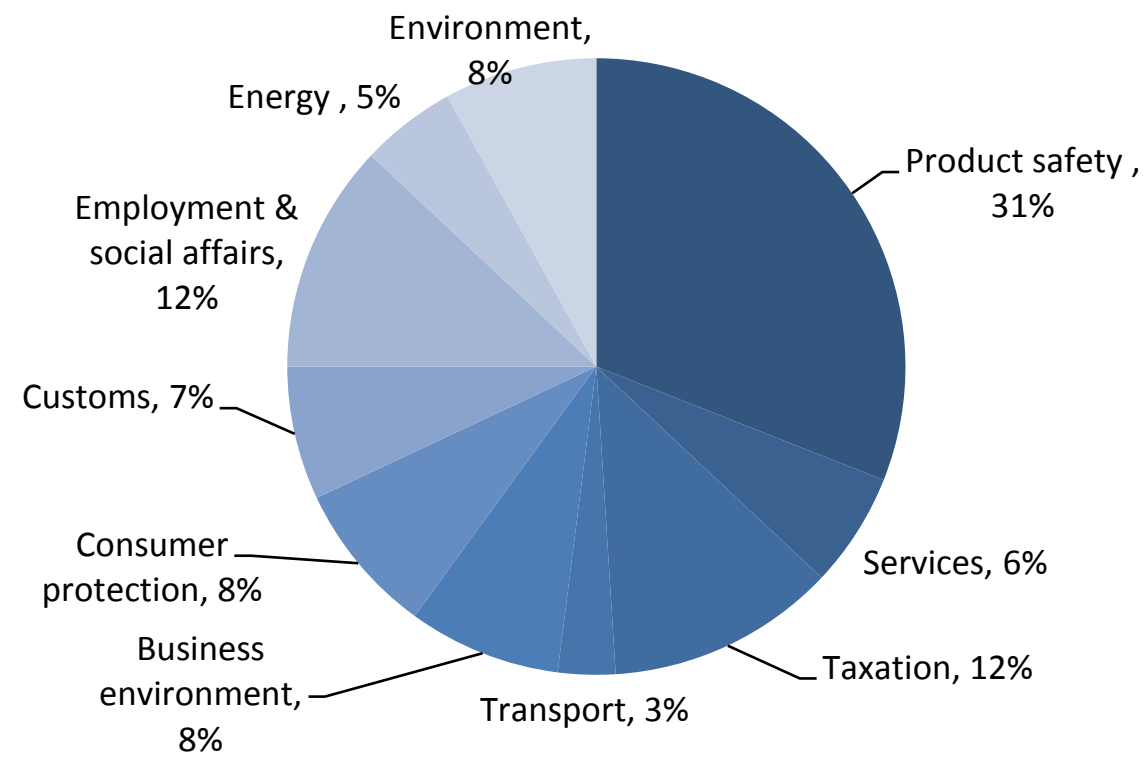

Source: EU Top 10.

As measured by the OECD Services Trade Restrictiveness Index (STRI) ${ }^{10}$ Greece has a higher STRI score than the sample average in 11 out of 18 sectors (Figure 16) with the most important restrictions identified in accounting services, air transport (covering commercial establishment only) and maritime services. According to the STRI impact analysis, even modest reforms in regulations that lower restrictions to services trade could increase exports by up to $7 \%$ and lower import prices by as much as $10 \%$ in some sectors and countries (OECD, 2014a).

${ }^{10}$ See http://www.oecd.org/tad/services-trade/regulatory-database-services-trade-restrictiveness-index.htm. 
Figure 16. Greek Services Trade Restrictiveness Index by sector and policy area

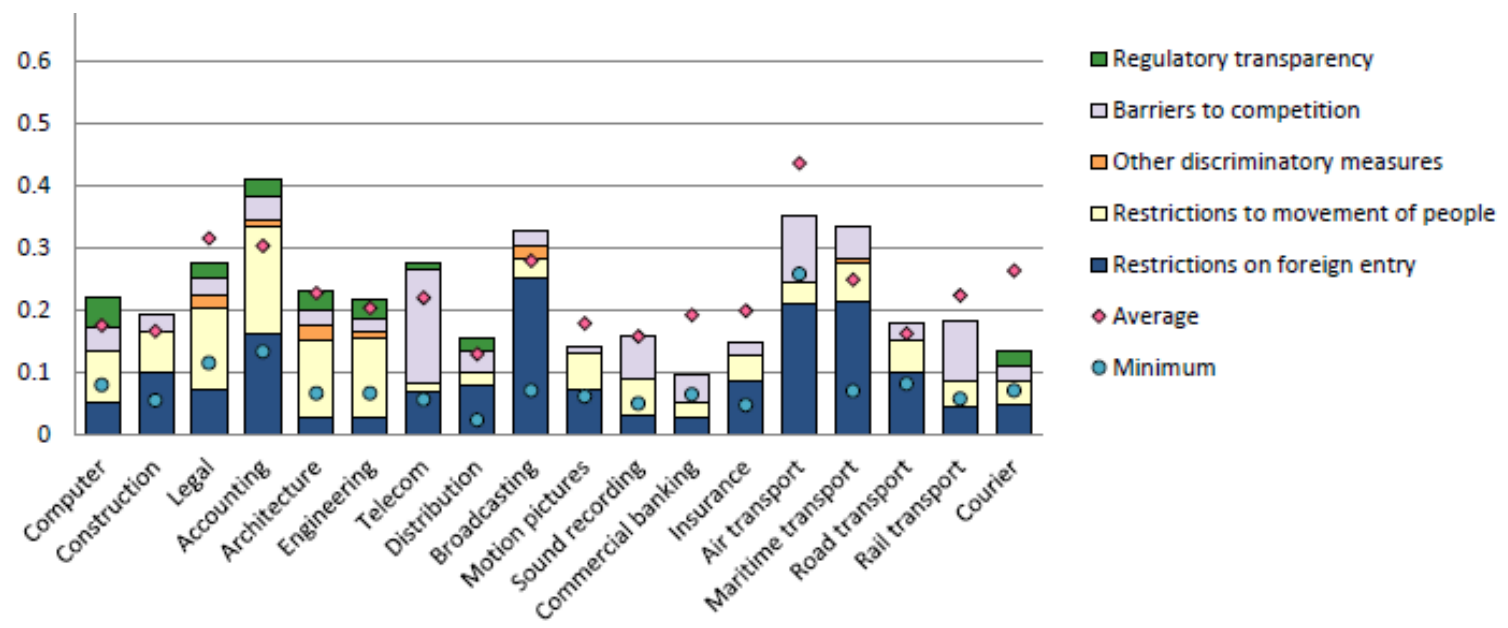

Source: OECD Services Trade Restrictiveness database.

Considerable reforms in the services sectors have been introduced as part of Greece's structural adjustment programmes, including efforts to foster transparency, improve the overall investment environment, and reform the public procurement market. Further implementation of structural reforms that enhance competition in services and promote a friendlier business environment could lower the STRI scores of Greece, improving the efficiency and productivity of the overall economy. This is particularly the case for backbone and infrastructure services, such as construction, transport and professional services (OECD 2014a).

\section{II.2.2. Restrictions in product markets}

Greece has had the largest improvement in the overall product market regulation (PMR) environment, as measured by the reduction in the OECD indicators of PMR (-0.47 in the overall score for the period 2008-13), which can be largely attributed to the sizeable structural reforms implemented in the past 5 years in the country (Koske et al., 2015). While substantial progress has been made, product market regulation in Greece remains significantly less business-friendly than the OECD average (Figure 17).

Greece scores high in the state control component of the PMR indicators, primarily driven by public ownership of firms in network sectors and poor governance of those firms. Barriers to foreign trade and investment are low. But when evaluating the regulatory stance at the sector level, Greece has one of the most restrictive regulatory environments across OECD countries in the energy, transport and professional services markets (Figure 18). Remaining barriers to competition impede export growth and addressing those restrictions could boost competition, exports and economic growth. 
Figure 17. Economy-wide PMR score in 2013

Index scale 0 to 6 from least to most restrictive, OECD countries, 2013

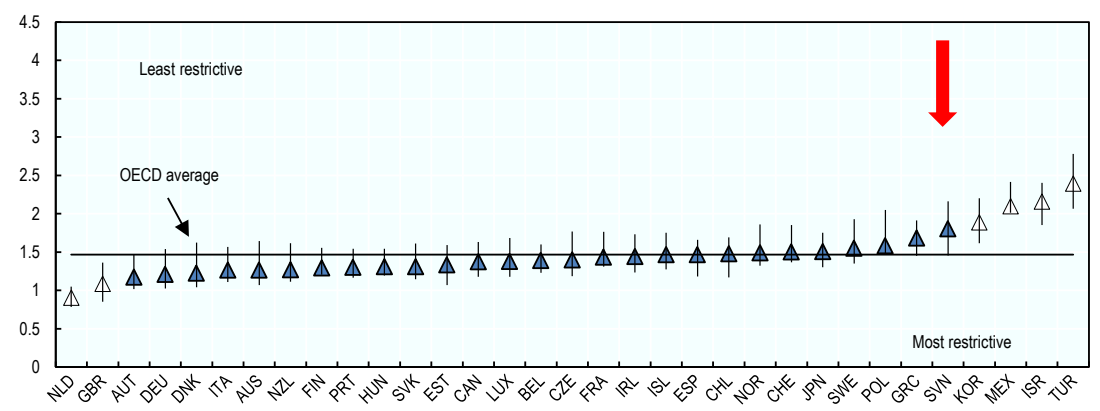

Source: OECD (2015i), Product Market Regulation Database.

Figure 18. Regulation of energy and transport services

(A) Regulation of energy services, index scale 0 to 6 from least to most restrictive

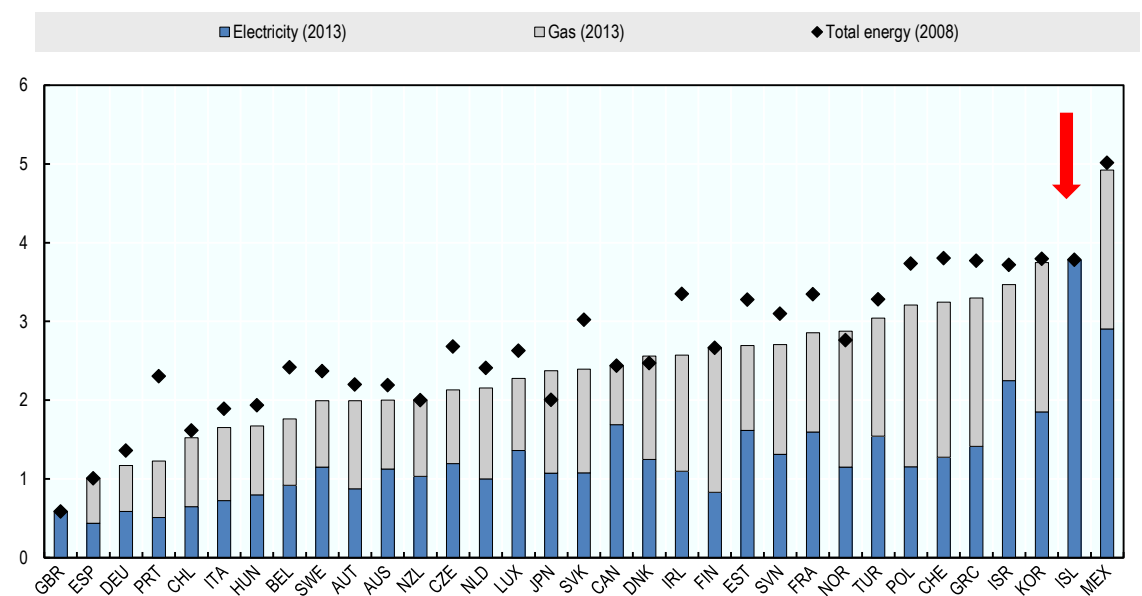

(B) Regulation of transport services, index scale 0 to 6 from least to most restrictive

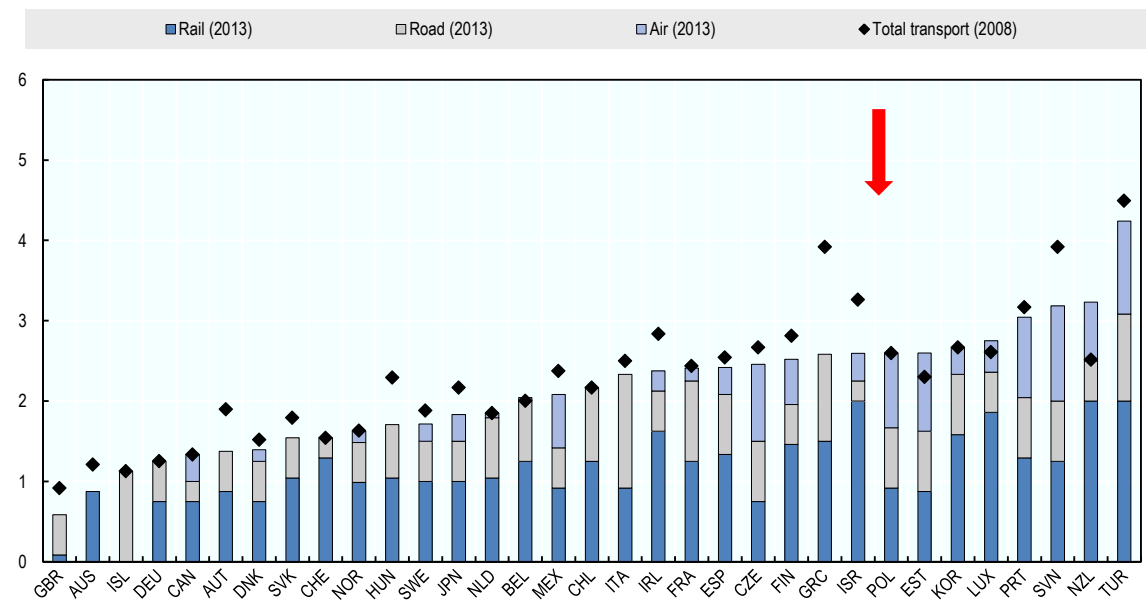

Source: OECD (2015i), Product Market Regulation Database. 


\section{II.2.3. Barriers to entrepreneurship}

Greece scores high in barriers to entrepreneurship (Figure 19). High scores in the barriers to entrepreneurship component of the PMR are typically driven by a strong protection of incumbents in network and services sectors and high administrative burdens on specific firms such as retail shops and road freight companies. According to the 2015-16 Global Competitiveness Index of the World Economic Forum, access to finance, inefficient government bureaucracy, and policy instability are the most problematic factors for doing business (WEF, 2015).

However, a marked improvement of the country's rankings in the World Bank's Ease of Doing Business rankings from the $109^{\text {th }}$ in 2010 to the $61^{\text {st }}$ position in 2014 (WB, 2015) signals the important reforms undertaken in the past few years. Similarly, in the 2015-16 Global Competitiveness Index of the World Economic Forum, the country ranks $81^{\text {st }}$ in $2015-16$ compared to $96^{\text {th }}$ in $2012-13$, with improved performance in the legal and administrative framework, labour market reforms being the most prominent underlying factors (WEF, 2015).

Figure 19. Barriers to entrepreneurship in 2013

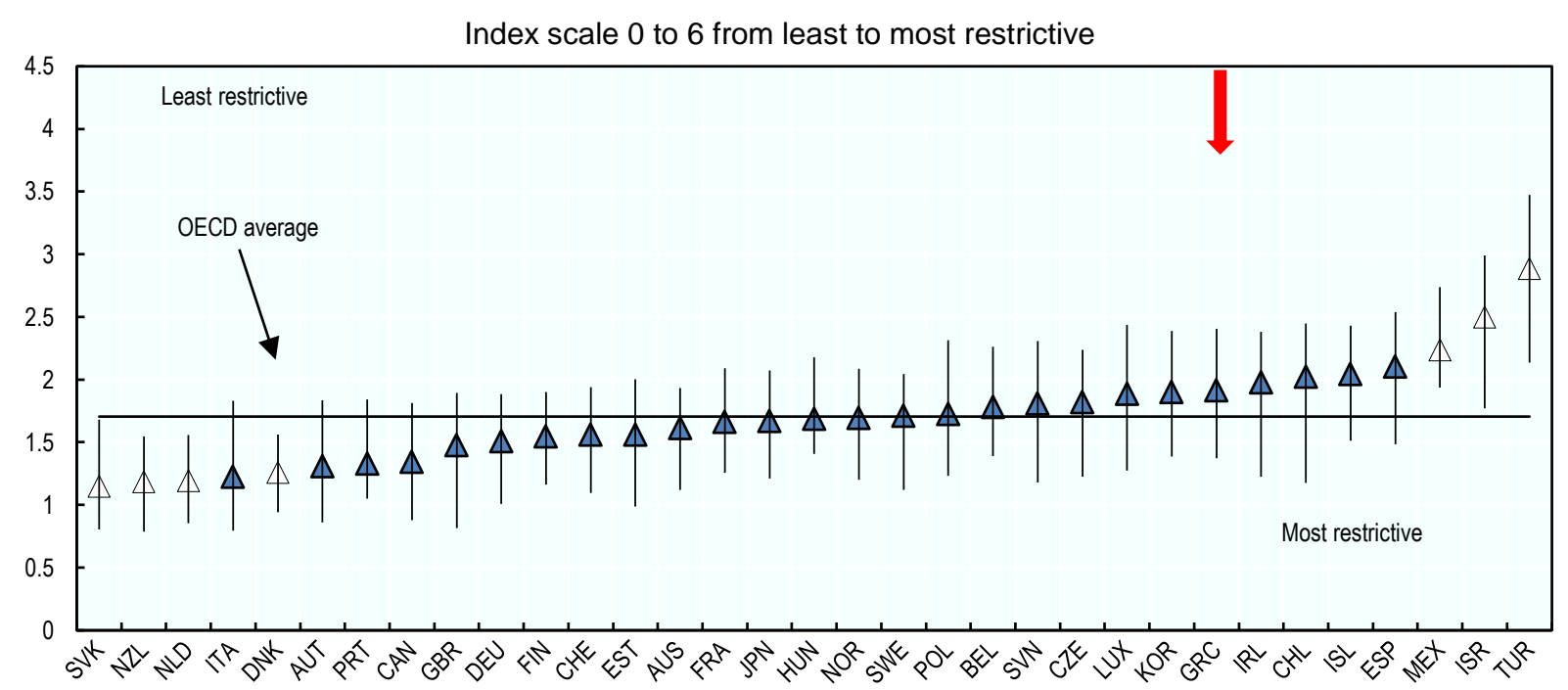

Notes: The index uses a scale of zero to six to evaluate: i) complexity of regulatory procedures (e.g. licences and permits system, communication and simplification of rules and procedures); ii) administrative burdens on start-ups (e.g. administrative burdens for corporations and sole proprietor firms, barriers in services sector) and iii) regulatory protection of incumbents (e.g. legal barriers to entry, antitrust exemptions, barriers in network sectors).

Source: OECD, Product Market Regulation Database.

\section{II.2.4. Reforms to tackle administrative opacity and reduce the cost of doing business}

The OECD has proposed a list of reforms to tackle administrative opacity and reduce the cost of doing business, identifying options for reducing red tape by reforming the public administration (OECD 2014b). The creation of a one stop shop, a physical or virtual place where business can obtain information and carry out transactions with a single point of contact in the administration, is another policy proposed with a view to increase the efficiency of the interaction of businesses with the public administration, reduce time needed for such interaction and promote the flow of information to 
businesses. The implementation of one stop shops for the purpose of the establishment of companies has contributed to the dramatic reduction in the cost of setting up a company and can constitute an important precedent for the enlargement of the purpose and scope of such entities.

The creation of a single integrated information system or 'national single window' for exports, as prescribed by the National Trade Facilitation Strategy (NTFS) for Greece is a similar concept of a one stop shop specifically for export procedures (Hellenic Republic, 2012). The NTFS encompasses a broad range of reforms aimed at simplifying export procedures, and its full implementation is expected to significantly alleviate the high cost and long time periods involved in administering exports. The simplification of pre-custom and custom procedures is expected to reduce time to export by $50 \%$ and costs by $20 \%$ by 2015 , thus leading to a $10 \%$ increase in export value, a $1.7 \%$ increase of GDP, and 80,000 new jobs.

The focus on streamlined, quick and digital procedures will be particularly helpful to SMEs who want to trade across borders, given that the high costs involved in previous lengthy procedures disproportionately affected the lower end of the size and turnover spectrum. The same applies to regulatory barriers, administrative burden or red tape related to the export process which translate into indirect costs to exporting companies that wish to set up exporting business or grow by internationalising.

Empirical studies have demonstrated the strong link between trade and institutional quality, and recent studies around Greek export performance suggest that institutional quality and quality of governance explain to a large extent $(54 \%$ - 78\%) the competitiveness gap of Greek exports when compared to the expected performance on the basis of Greek GDP, the size of its trading partners and their geographical distance (Böwer et al., 2014). The underperformance of the country's institutional set up is also confirmed by the OECD Sustainable Governance Indicators (SGI), with Greece remaining the lowest-ranked country (rank 41) in the SGI 2015 with regard to economic policies. ${ }^{11}$

To achieve a sound, transparent and efficient regulatory environment coordination at all levels of government is needed. In particular, when considering subnational levels, the challenge of avoiding duplication or superposition of norms is higher, as is the risk of applying regulations unequally. The aim of subnational regulatory policies could be to increase social welfare and to stimulate local economic development, but this may require organising and reassessing local laws, in particular towards SMEs, and enhance awareness of such regulation.

Based on the above, structural reforms remain the key to lowering the barriers and costs of export-orienting companies, encourage the internationalisation of SMEs and unlock the growth potential of the economy that lies in its export performance. Structural reforms that tackle administrative burden and improve the business climate can also have a direct positive impact on investor appetite for (foreign) direct investment in the Greek economy.

The provision of a stable tax framework has long been argued by investors to be one of the most pressing issues, while a stable tax code with a focus on reducing the tax burden on entrepreneurs is considered as a prerequisite for the rebound of investments (Bank of Greece, 2014).

\footnotetext{
${ }^{11}$ http://www.sgi-network.org/2015/Greece.
} 


\section{II.2.5. Effective dispute resolution mechanisms}

Investor protection and contract enforcement, supported by the legal framework, are additional factors that affect private investment, and should be improved with the implementation of agreed structural reforms in Greece. Effective insolvency regimes allow unviable firms to exit the market and their orderly resolution. The process should be transparent and clear, and bankruptcy procedures should be accelerated.

A rigid and costly insolvency regime involved, until recently, inefficient and lengthy corporate resolution mechanisms. In addition to being unable to deal with either the rapid rehabilitation of viable entities or the quick liquidation of non-viable entities (IMF, 2014), the country's insolvency framework has so far not allowed for the possibility of a "fresh start" to be provided to insolvent entrepreneurs, if and when appropriate (Athens' Chamber of Tradesmen, 2015). Amendments to the corporate insolvency law, required in the August $2015 \mathrm{MoU}$, aim to bring the law in line with international best practice and include changes to promote effective rehabilitation of viable debtors and a more efficient liquidation process for non-viable debtors, reducing the discharge period to 3 years for entrepreneurs, in line with the 2014 EC Recommendation (EC, HR, BoG 2015). 


\section{PROMOTING R\&D AND INNOVATION FOR PRODUCT UPGRADING IN GVCS}

In order to boost the value added of exports, including by SMEs, Greece can benefit from more investments in $R \& D$, from the existing stock of highly skilled labour, and from further synergies between universities, firms, and research institutions. Moreover, the country scores above average in terms of positive attitudes towards entrepreneurship. In addition, the natural potential of the country in terms of renewable energy sources (e.g. solar and wind) places Greece in an advanced position to lead the research and innovation in green energy.

\section{III.1. A mismatch of low R\&D investment and a valuable stock of human capital}

Despite weaknesses in the institutional framework of post-secondary education, Greece disposes of an important stock of human capital, with one of the highest proportion of entrants in tertiary education in engineering, science and health amongst OECD countries (Figure 20). The economic recession had repercussions on the human resources of the country, with a reported high number of young scientists and researchers driven out of the country. Prioritising the promotion of public and private $R \& D$ and innovation activities could assist in containing the reported brain drain of scientists and researchers who choose to move abroad due to underemployment or unemployment at home.

A puzzling mismatch is observed in Greece between low R\&D spending and a proportionately better performance in terms of international publications and presence amongst the world's top universities (Figure 21). Corporate R\&D investment is also lacking, and the low values of innovation output of Greek firms are thought to be a direct consequence of their low innovation input (OECD, 2014d). Further cuts in public research spending in the context of fiscal consolidation call for greater participation of private capital in $R \& D$ investment and greater links between the industry and the country's research institutions.

Figure 20. A valuable stock of human capital

Percentage of entrants to tertiary education in engineering, science and health fields, 2012

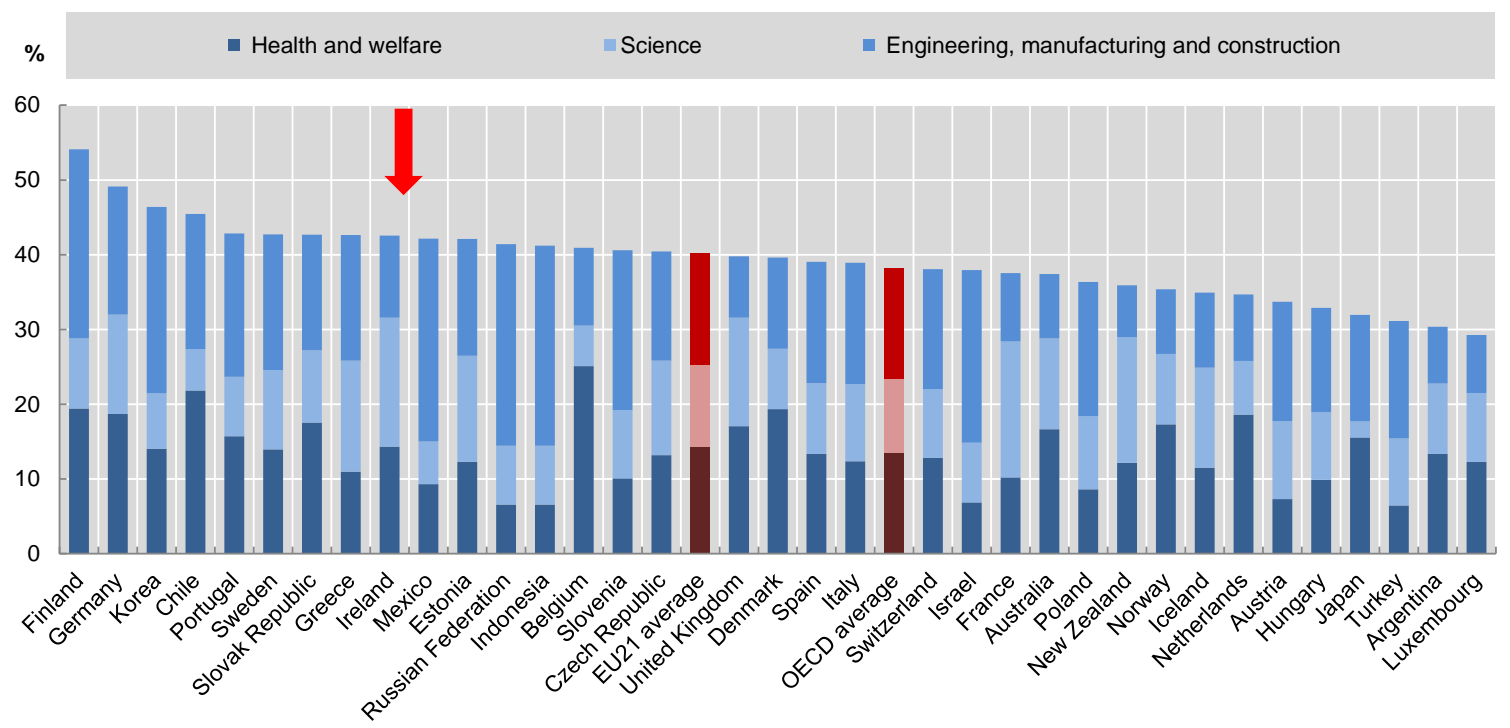

Source: OECD (2014e). 
Figure 21. Comparative performance of national science and innovation systems, as of 2014
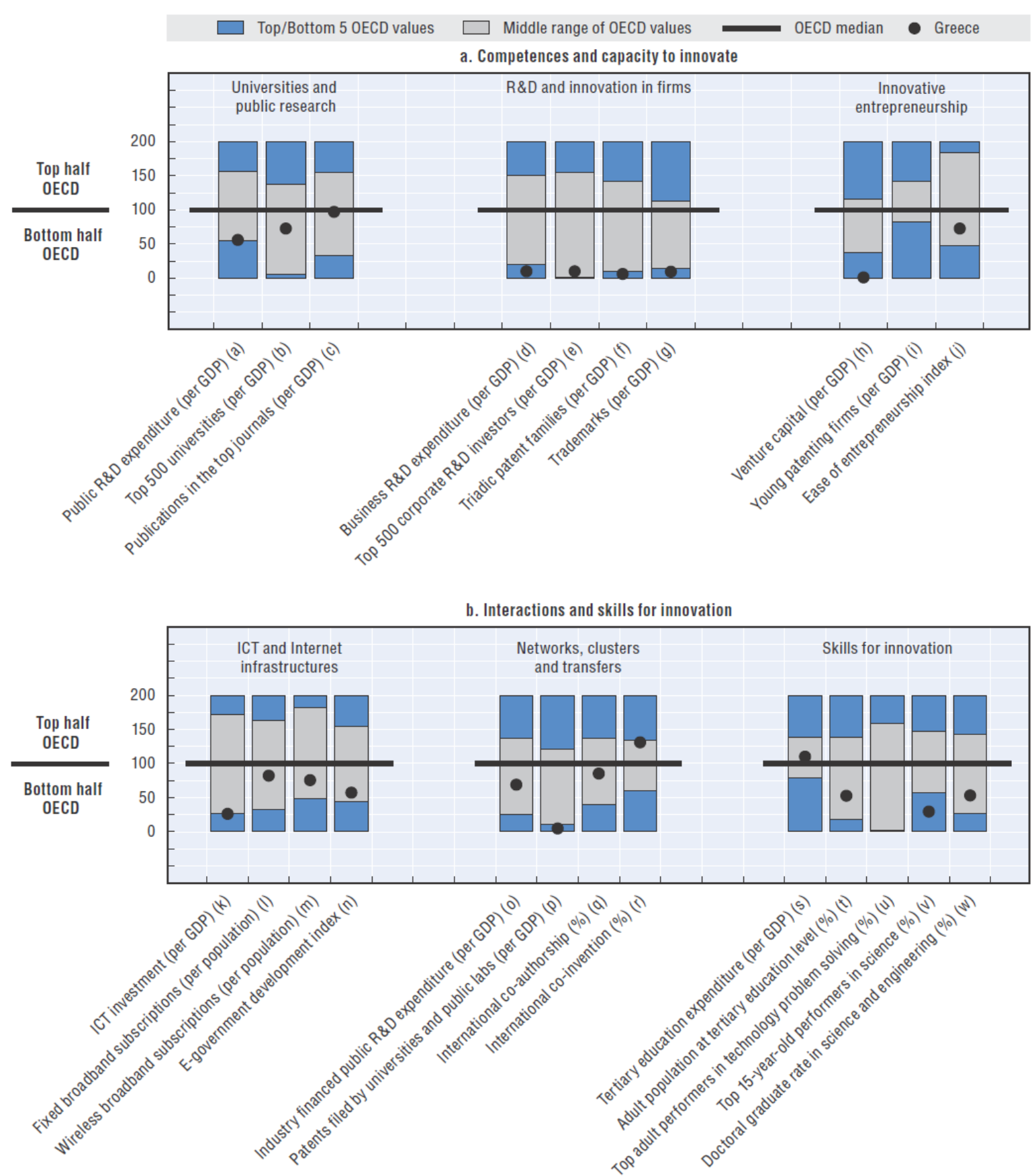

Note: Normalised index of performance relative to the median values in the OECD (Index median $=100)$.

Source: OECD (2014d).

Despite a very high performance in terms of co-inventions, Greece is a clear laggard in terms of commercialisation of these innovations, as evidenced by the low number of patents filed by Universities and research labs. In effect, research centres and universities are largely insulated from the productive sector (OECD, 2014d). The absence of links between universities and the industry, as 
well as the very limited flow of venture capital funds into innovation produced by universities hampers the application of new technologies and the commercialisation of such innovation.

\section{III.2. The triple helix ${ }^{12}$ of innovation, entrepreneurship and public policy and the role of clusters}

The positive attitudes towards entrepreneurship by the Greek population may suggest that the absence of commercialisation of research and innovation produced is not necessarily due to a conscious abstaining from entrepreneurial action (Figure 22A). Such positive attitudes are particularly prominent across the young population; according to a study by Endeavor Greece, $81 \%$ of students in Greece have a positive attitude towards entrepreneurial activity vs. a small minority of $4 \%$ being negative or very negative attitudes (Endeavor Greece, 2015). At the same time, perceived opportunities for entrepreneurial activity are very low, especially when compared to perceived capabilities, and the country ranks the highest amongst OECD countries in terms of fear of failure (Figure 22B).

Figure 22. Positive attitudes towards entrepreneurship clouded by a high fear of failure

(A) Attitudes towards entrepreneurship, in percent of respondents, 2014

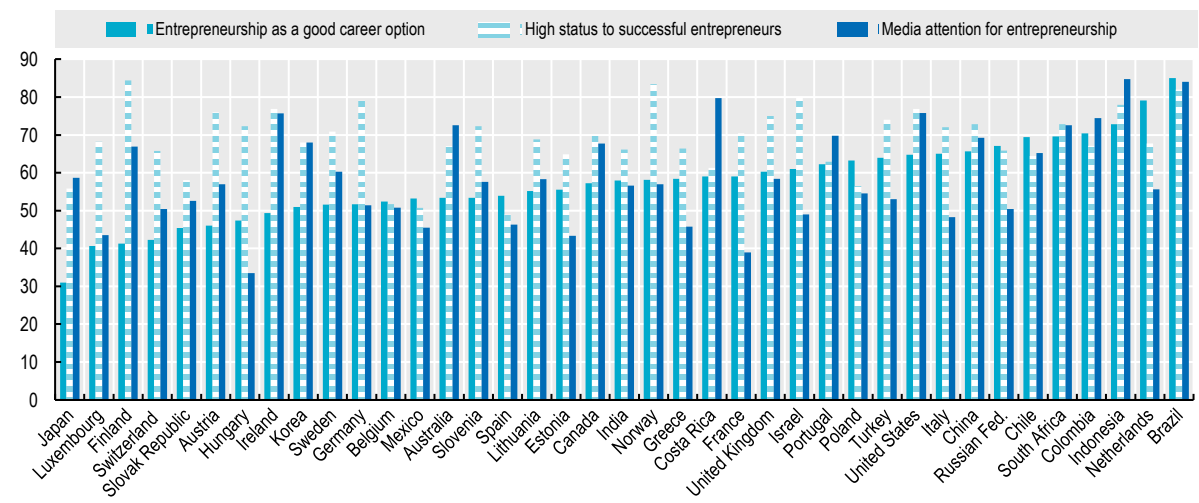

(B) Entrepreneurial perceptions, in percent of respondents, 2014

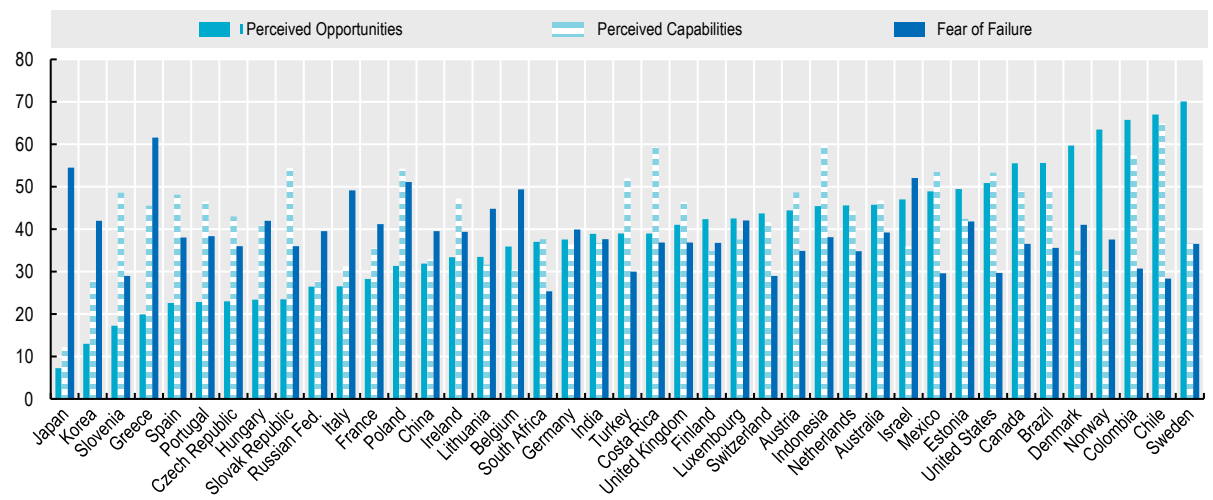

Source: OECD (2015b).

\footnotetext{
12 Term first coined by Etzkowitz and Leydersdorff (Etzkowitz and Levderdorff, 1995) for innovation-based policy development based on three poles: intellectual/academia, business and government.
} 
Fear of failure may be linked to the country's insolvency framework and the 'stigma' associated with entrepreneurial failure as a consequence of that (see Section II.2.5). In addition to being unable to deal with either the rapid rehabilitation of viable entities or the quick liquidation of non-viable entities (IMF, 2014), the country's insolvency framework has so far not allowed for a "fresh start" to be provided to insolvent entrepreneurs, if and when appropriate (Athens' Chamber of Tradesmen, 2015).

In order to help develop high-value added exports, stronger links can be built between academia, other research centres, and the real economy, in particular private investors (such as venture capitalists) and entrepreneurs. As of 2012, only $18 \%$ of Greek SMEs had some sort of collaboration with Universities or other types of higher education institutions in 2012 (National Documentation Centre, 2015).

Entrepreneurs can translate innovative technologies and concepts into products and services that can be commercialised through start-up companies and reach new markets that demand these new products and services. The export potential of such activity is significant also when considering the prominent role that services play in the coordination and linking of stages and partners in GVCs (Figure 23). Services linked to logistics, communication, IT, network infrastructure are important for the production and co-ordination of GVCs. Such services can be fostered and enhanced through innovation, differentiating and adding value to them in the process (OECD, 2013e).

Figure 23. Services are key to the efficient operation of GVCs

Services value-added content of gross manufacturing exports, as a percentage, 2009

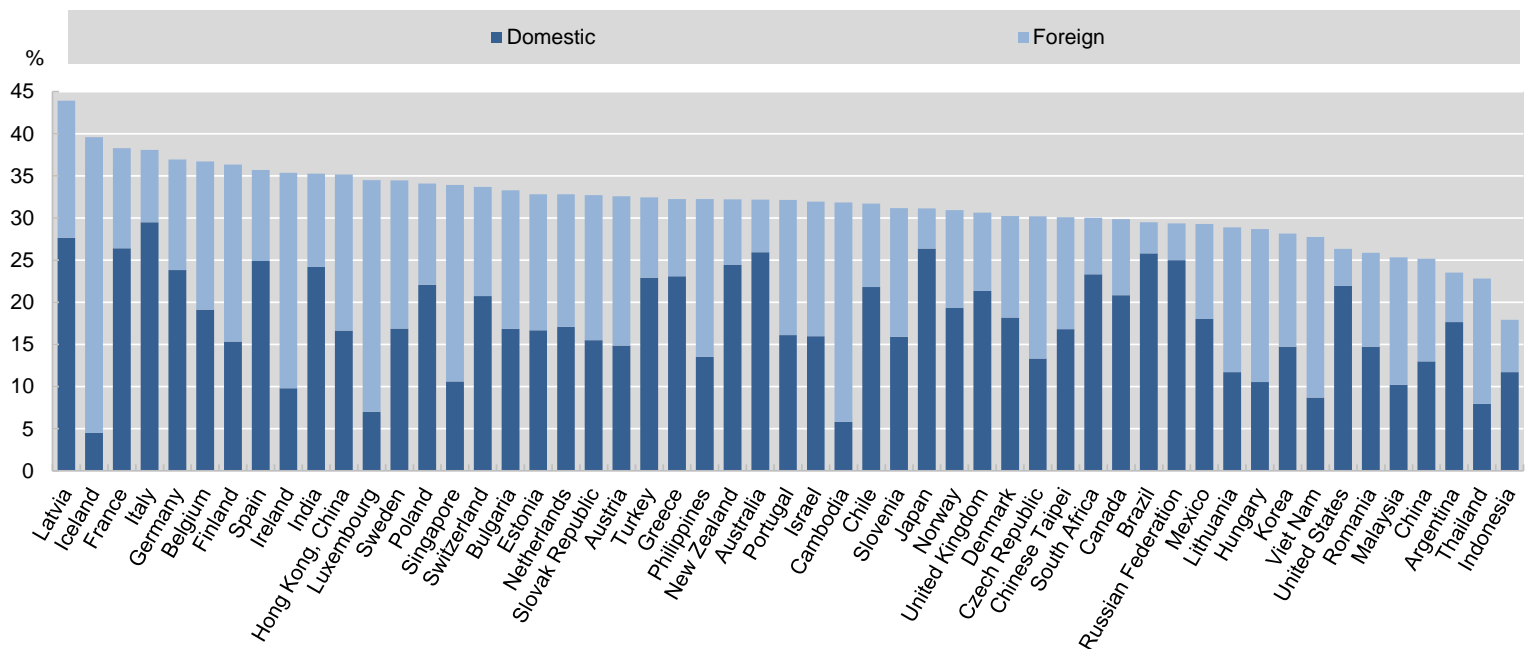

Source: OECD (2013d).

Greater integration of SMEs in GVCs can improve their profitability prospects, allowing them better access to financing, and at better terms. Greek banks are currently considering innovative financing products to provide liquidity and credit for Greek SMEs participating in viable GVCs at local and international levels. An initial project targeting agricultural business financing is expected to be expanded to sectors where Greece has a competitive advantage, such as shipping and tourism. An innovative programme for SMEs participating in shipping GVCs, comprising of financing, product certification and incentives for product upgrading allowed 37 SMEs participating in the construction of a ship to secure financing for the entirety of their production against the purchase contracts for the ship by the final client. By regarding those SMEs participating in such GVCs as clusters, financing 
becomes easier due to synergies and lower risk (secured by the purchase contract for the final product) which then translates into better credit terms for the SMEs.

Greek SMEs' participation in GVC is evidenced by Figure 24 (preliminary data, National Documentation Centre, 2015). While the share of the production process implemented abroad is 41.6 $\%$ for small firms (compared to $51.4 \%$ for large ones), the use of intermediate foreign products by Greek SMEs is $58.4 \%$ (compared to $48.6 \%$ of large firms). When it comes to exports, the entrepreneurial exploitation of innovation can upscale the complexity and quality of exported products, increasing the value added and improving participation of Greek SMEs in GVCs. This can be accomplished through product upgrading, i.e. the supply of higher value added products, mainly through superior technological sophistication and quality (OECD, 2013e). More than an enabler, innovation is actually considered to be a requirement for the successful participation of SMEs in GVCs (OECD, 2007).

Figure 24. Participation of Greek firms in GVCs

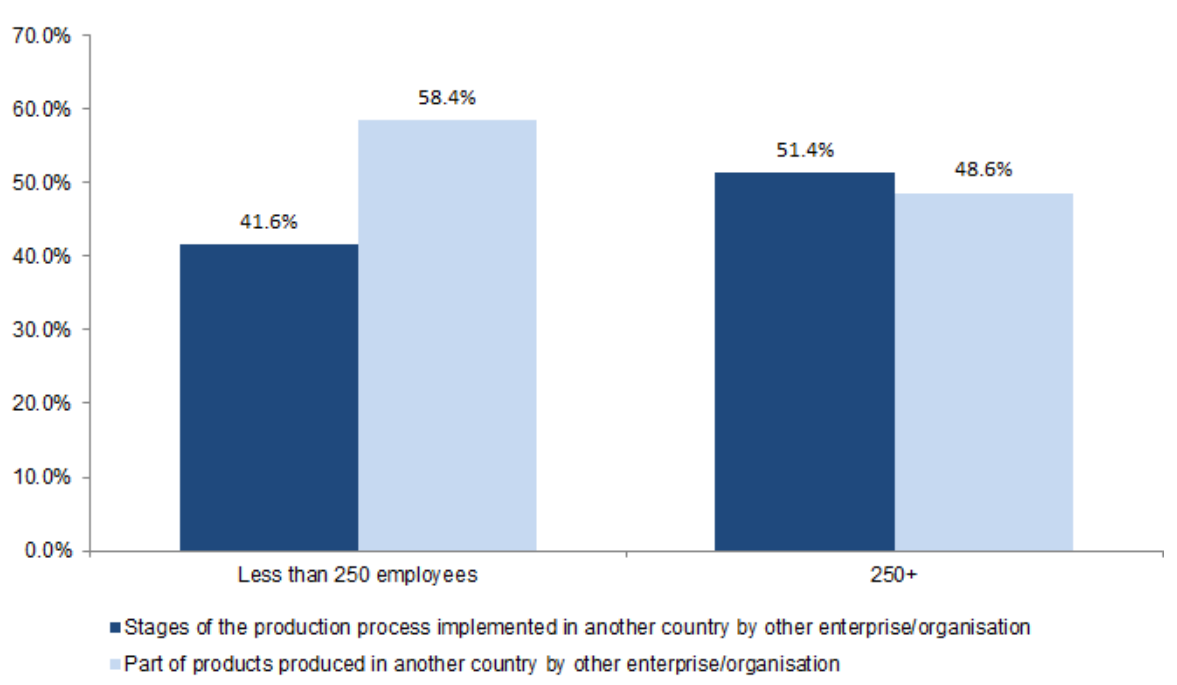

Source: National Documentation Centre (2015).

The Investment Law (3908/2011) amended in 2012-13 puts more emphasis on young innovative entrepreneurship, on improving the climate for business investment in $R \& D$ and on green development (OECD, 2014d). Greece has devised a new legal framework for research and technological development that includes both a long-term strategic framework and an action plan, aimed at addressing emerging and long-standing science, technology and innovation challenges in the country. The action plan for research and technology establishes more favourable conditions for R\&D, simplifies financing procedures and facilitates the activities of research organisations. Among the quantitative targets, the new plan intends to raise R\&D expenditures to $1.5 \%$ of GDP by 2020, half the target of Belgium, Estonia, Germany, Norway and Portugal for the same period (OECD, 2014d).

The role of public policy shouldgo beyond the provision of a business- and investor-friendly environment, to acting as a facilitator and catalyst for the development of clusters and networks.

Cluster policy is a broad concept that encompasses public actions addressing market failures in regions (either lagging or leading); sectors within a region (dynamic or of strategic or social importance), or actors (either large or small firms, universities and research centres, or combinations of them). Cluster policies allow for the diffusion of technology and knowledge across nodes (e.g. 
service providers, universities, firms). The intensity of the intervention might vary: from facilitation and intermediation roles aiming to connect producers and suppliers, to dedicated projects supporting targeted sectors, regions, or actors (OECD, 2015h). The instruments used in cluster policy depend on the identified market failure, addressing access to finance, the regulatory environment, transferring knowledge, or supporting trade linkages. ${ }^{13}$

The Corallia Clusters Initiative ${ }^{14}$ is the first example of an innovation cluster established in Greece, and has benefited from around EUR 40m of EU support since its launch in 2006. Its strategic aim is to catalyse the development of cohesive and productive innovation ecosystems in areas where a competitive advantage and exports orientation exists. It provides incubating services and acts as a cluster facilitator, having developed and supported the growth of three highly-specialised cluster initiatives in knowledge-intensive sectors. In this context, Corallia acts as a one-stop-shop, supporting new venture creation, it promotes complementarities and partnerships among cluster-members and between cluster-members and national and international organisations, it enhances technology transfer and R\&D commercialisation in the thematic technology area of the clusters, and it creates a favourable environment to attract VC and business angel investors. Financial support through public initiative for such cluster environments, as could potentially be the case through the planned Innovative Business Fund, could support innovative businesses and research, backing entrepreneurial activity that links the two (Kathimerini, 2015).

\section{III.3. Diversification of the export base through a reorientation towards innovation and product upgrading}

The currently low technological intensity of Greek exports, along with the highly skilled population, provide an opportunity for the possible diversification and expansion of the export base and its reorientation towards investment in $\mathrm{KBC}$ and innovative products and services. Indicative areas with high potential range from green tech and sustainable management of natural resources, to information technology, pharmaceuticals, diversified tourism (e.g. medical, business), as well as creative and cultural industries.

Tourism has been the backbone of the Greek economy, particularly in the years of the crisis, recording the highest contribution to GDP and employment amongst OECD countries (OECD, 2014f). Diversification and upgrading of tourism services beyond the classical "sun, beach and sand" with low value added can be achieved by making use of the country's valuable stock of human capital, and as R\&D and innovation develop into viable and sustainable activities they may feed into the touristic products. Such diversification and upgrade of touristic services has the potential to tackle the high seasonality currently facing tourism. Medical tourism is an example of alternative forms of tourism which has already started to develop in Greece (cosmetic surgery, fertility treatments, dental and eye treatments). Business and conferencing, educational or medical tourism promote the expansion of the export base through higher value added services and the upgrading of the products and services involved. ${ }^{15}$

${ }^{13}$ Cluster policies targeting SMEs are generally designed at the subnational level. Therefore, a whole of government approach is necessary to ensure that regulations are not duplicated, interfering with each other or inconsistent with overall policy objectives.

${ }^{14}$ www.corallia.org

${ }^{15}$ The diversification of touristic products could also benefit from enhanced infrastructure, especially in the areas of transportation (e.g. modernisation of airports, ports and highways), as with the currently ongoing public-private cooperation schemes developed in the context of the Greece's privatisation programme. 
Cultural and creative industries, combining innovation and personal creativity, are recognised as an emerging dynamic segment that intertwines knowledge and new technologies with the economy of culture and creativity (Lazaretou, 2014). Greece could take advantage of not only of its 'natural' competitive advantage as holiday destination but also reap the potential benefits of smart, creative industries in order to achieve inclusive and sustainable economic activity and growth.

Figure 25. Low broadband penetration and e-commerce activity compared to other OECD countries

(A) Broadband penetration, as a percentage of enterprises in the same size category

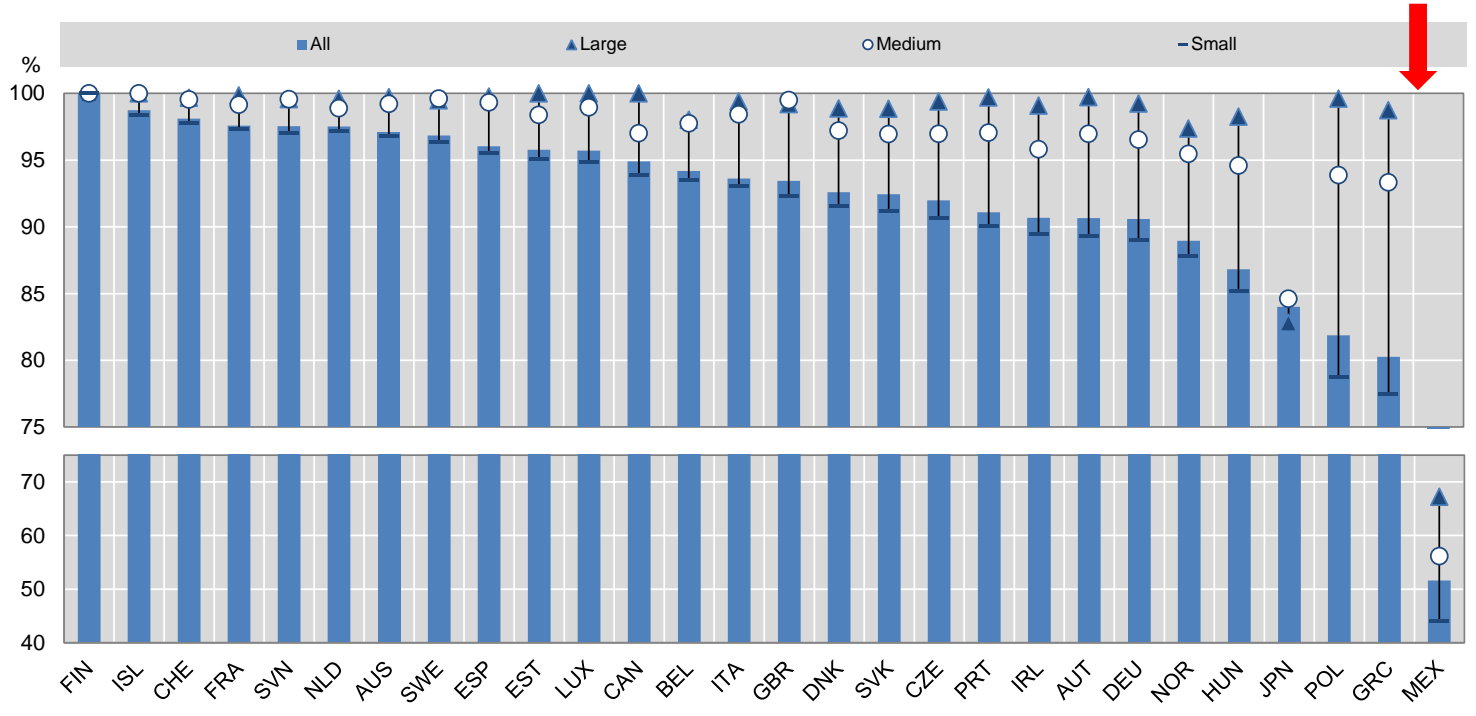

(B) Enterprises selling online, as a percentage of enterprises in the same size category

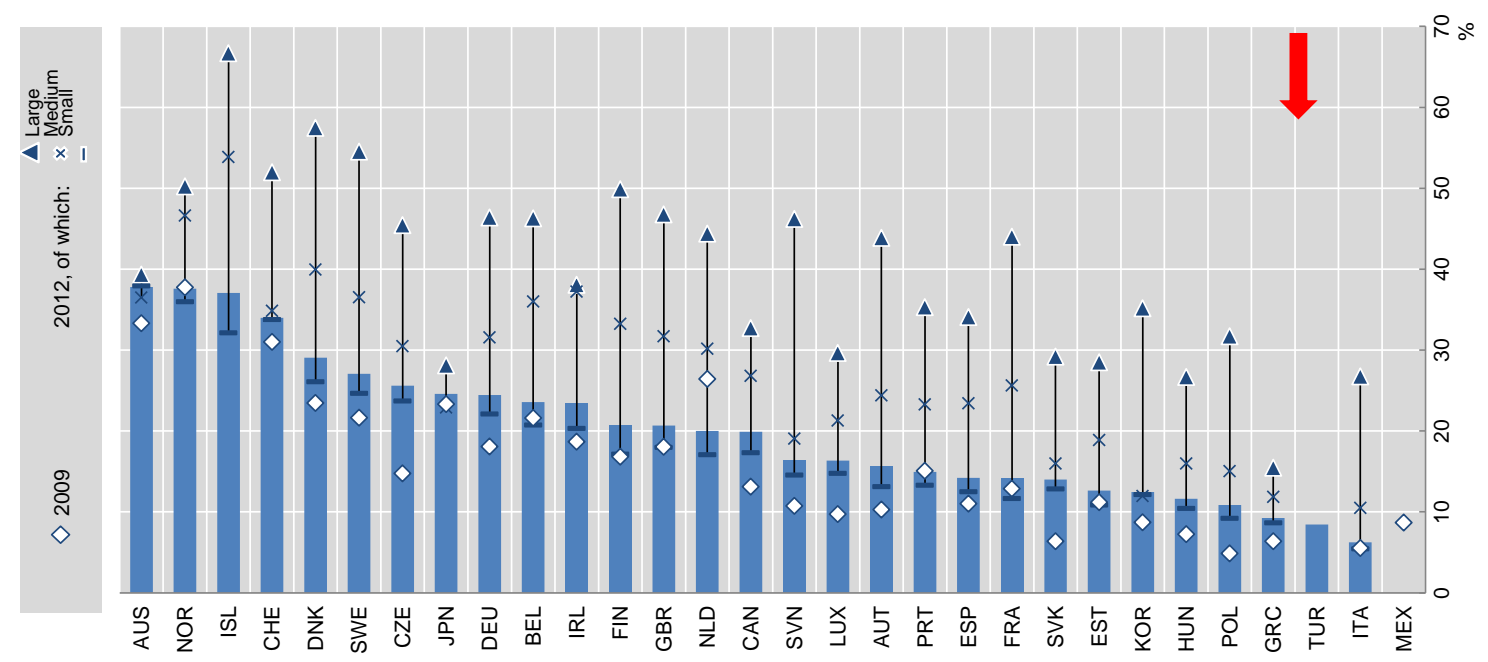

Source: OECD (2013a).

The insular characteristics of the country's geography, with many remote islands, make infrastructure investments a particular challenge, but the digitalisation of services and internet access can help to overcome this situation. At present, there is limited e-commerce activity, potentially linked to a low broadband penetration compared to most OECD countries, which further limits the international activity of SMEs, particularly at the low end of the size spectrum (Figure 25). This is also 
reflected in the low use of electronic channels for transactions and payments observed. With electronic commerce being perhaps the easiest way for micro SMEs to export and reach new markets, there is a large scope for small SMEs to engage more in e-commerce activity. Both the lack of financial education and related skills, as well as network connectivity and costs need to be examined and addressed to that end. 


\section{POLICY-RELATED CONCLUSIONS}

Policy-related conclusions and potential policy action are summarised in Box 3.

\section{Box 6. Policy-related conclusions and potential policy action}

Finance

- The reinforcement of the financial sector and the resolution of the NPL challenge is expected to contribute to the restoration of access to finance for SMEs and credit expansion for the economy overall. Simple, transparent and standardised securitisation of SME loans (and other liabilities) can be used as a market-based shortcut to indirectly foster SME financing without the complete disintermediation of banks, by creating headroom in banks' balance sheets and allowing them to further on-lend to SMEs. Banks are required to keep some "skin in the game", ensuring robust origination practices are followed.

- $\quad$ Capital market financing (bonds, private placements, listed equities) through established platforms tailored to SMEs with proportionate costs and requirements could be promoted as complementary to (rather than a substitute for) bank lending. Banks remain best placed to originate the bulk of small-sized loans to the micro-dominated SME space in Greece.

- Promoting financial education of SMEs, raising awareness of existing official sector support programmes could increase their take up, as well as of alternative financing instruments available. Additional measures to this effect are equipping SMEs with the skills necessary to make use of support schemes and/or alternative debt and equity financing instruments.

- The mandate of the recently established Institution for Growth (IfG) could be expanded along the lines of a typical public financial institution (PFI), centralising and streamlining agencies and programmes for SMEs. Such a PFI should also provide non-financial services (financial education, capacity building, and raising awareness about best-suited financial instruments) to exporting SMEs with viable projects, and increase their absorption and uptake of available support schemes. The institution should also be in charge of ensuring coherence across different private and government agencies fostering export financing and SME financing in general.

- Encouraging of ongoing reporting and data-sharing by SMEs would greatly facilitate lending to viable SMEs while also supporting market-based financing. The build-up and sharing of credit ratings in centralised platforms could reduce information asymmetries and the cost of issuing market-based financing by SMEs.

\section{Regulation}

- A stable tax framework and legal environment as part of a friendlier business environment will allow private investors such as venture capitalists to deploy funds in local SMEs.

- Careful implementation of policies that will reduce the administrative burden for businesses, in particular when it comes to exporting processes, should be envisaged - as in the case, for example, of the National Trade Facilitation Strategy and Roadmap (underway). Careful implementation of additional product market reforms that will improve competition conditions and will facilitate new entrants (underway) will also help.

- The implementation of a more efficient restructuring and resolution framework, coupled with improvements in the insolvency regime (underway), should allow for the quicker exit of insolvent SMEs and the efficient debt (but also operational) restructuring of viable SMEs. The availability of 'fresh start' possibilities for failed SMEs and entrepreneurs would reduce the stigma associated with failure and promote entrepreneurial risk-taking.

R\&D, Innovation and Clusters

- Greater emphasis should be put on developing venture capital financing. Stronger links and networks/clusters between universities, innovation and venture capital suppliers can facilitate the commercialisation of research and innovation, promote entrepreneurship and strengthen SME insertion in global value chains.

- $\quad$ The design and development of cluster policies and initiatives can support knowledge transfer and technology diffusion while at the same time reinforce trade linkages and ease the flow of financing for participating companies. 


\section{REFERENCES}

Athanasoglou, P., I. Asimakopoulos and S. Siriopoulos (2006), "External financing, growth and capital structure of Athens Exchange companies", Bank of Greece, Economic Bulletin No 26, available at www.bankofgreece.gr/BogEkdoseis/econbull200601.pdf

Athens' Chamber of Tradesmen (2015), Press release on Insolvency code - Second chance.

Bank of Greece (2013), Monetary Policy Annual Report 2012-13, May, available at www.bankofgreece.gr/BogEkdoseis/NomPol20122013_en.pdf

Bank of Greece (2014), Monetary Policy Annual Report 2013-14, June, available at www.bankofgreece.gr/BogEkdoseis/NomPol20132014_en.pdf

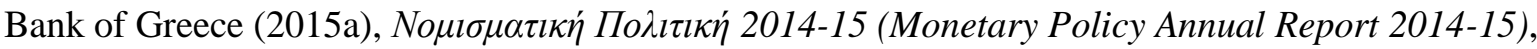
June, available at www.bankofgreece.gr/BogEkdoseis/NomPol20142015.pdf

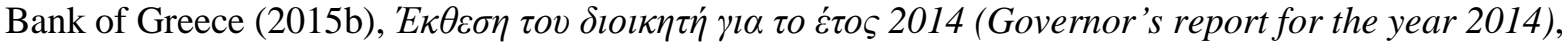
available at www.bankofgreece.gr/BogEkdoseis/ekthdkth2014.pdf

Bardakas, I. (2014), "Financing exports of goods: a constraint on Greek economic growth", Bank of Greece Working Paper 178, March, available at www.bankofgreece.gr/BogEkdoseis/Paper2014178.pdf

Berman, N. and J. Héricourt (2010), "Financial Factors and the Margins of Trade: Evidence from Cross-Country Firm-Level Data", Journal of Development Economics 93, 93.2 (2010): 206-217.

Bergthaler, Kan, Liu and Monaghan (2015), "Tackling small and medium sized enterprise problem loans in Europe", IMF staff discussion note, available at https://www.imf.org/external/pubs/ft/sdn/2015/sdn1504.pdf

Böwer U., Vasiliki Michou, Christoph Ungerer (2014), "The Puzzle of the Missing Greek Exports", Economic Papers 518, June, available at http://ec.europa.eu/economy_finance/publications/economic_paper/2014/pdf/ecp518_en.pdf

Bruhn M. and B. Zia (2011), "Stimulating Managerial Capital in Emerging Markets: The Impact of Business and Financial Literacy for Young Entrepreneurs", World Bank Policy Research Working Paper 5642, available at https://openknowledge.worldbank.org/bitstream/handle/10986/3406/WPS5642.pdf?sequence=1

Crespi, G., E. Fernández-Arias and E. Stein (2014), Rethinking Productive Development: Sound Policies and Institutions for Economic Transformation, Inter-American Development Bank, available at: www.palgrave.com/page/detail/rethinking-productive-development-interamericandevelopment-bank/?isb=9781137405593 
Dimitropoulou, D., A. Koutsomanoli-Filippaki, E. Haralambakis, G. Aggelis (2014), "Greek corporate financing prior and during the crisis", Bank of Greece, Economic Bulletin No 39, available at www.bankofgreece.gr/BogEkdoseis/oikodelt201407.pdf

ECB - European Central Bank (2013), "Corporate finance and economic activity in the euro area", Occasional Paper Series 151, available at https://www.ecb.europa.eu/pub/pdf/scpops/ecbocp151.pdf

ECB - European Central Bank (2015), Survey on the access to finance of enterprises in the euro area October 2014 to March 2015, June 2015, available at https://www.ecb.europa.eu/pub/pdf/other/accesstofinancesmallmediumsizedenterprises201411.e n.pdf.

EC - European Commission, Hellenic Republic, Bank of Greece (2015), Memorandum of Understanding for a three-year ESM programme; available at ec.europa.eu/economy_finance/assistance_eu_ms/greek_loan_facility/pdf/01_mou_20150811_e n.pdf.

EC - European Commission (2014), Task force for Greece, Seventh activity report, July, available at http://ec.europa.eu/greece/pdf/7thtfgractivityreporten.pdf.

EIB - European Investment Bank (2014), The EIB Trade Finance Facility for Greece: your secure bridge, available at www.eib.org/attachments/country/eib_tff_for_greece_en.pdf.

Endeavor Greece (2015), A youth perspective on entrepreneurship: something is changing, 1 December, available at http://endeavor.org.gr/wp-content/uploads/2015/12/Infographic_EN.jpg

Etzkowitz, Henry and Loet Leydesdorff (1995), The Triple Helix -- University-Industry-Government Relations: A Laboratory for Knowledge Based Economic Development (January 1, 1995).

EASST Review, Vol. 14, No. 1, pp. 14-19, 1995, available at http://ssrn.com/abstract=2480085

European Association of Public Banks (2010), 2009-2010 Annual Report of the European Association of Public Banks, Brussels: EAPB, available at www.eapb.eu/file?fle $=6089$.

HCPCM - Hellenic Confederation of Professionals, Craftsmen and Merchants (2015), HCPCM and Institute for Small Enterprises of the Hellenic Confederation of Professionals, Craftsmen and Merchants Survey on Small Companies, July 2015, available at www.imegsevee.gr/attachments/article/1052/survey_july2015_en.pdf

Hellenic Republic (2012), National Trade Facilitation Strategy and Roadmap, October 2012, available at www.unece.org/fileadmin/DAM/trade/GreeceTradeFacilitationReforms/Documents/NationalTr adeFacilitationStrategyRoadmap.pdf

International Monetary Fund (2014), Fifth review under the extended agreement under the extended fund facility.

Jemec, N. (2015), Dealing with non-performing loans in Greece, OECD internal background paper. 
Kathimerini (2015), Innovative business fund is getting there, 15 November, available at www.ekathimerini.com/203441/article/ekathimerini/business/innovative-business-fund-isgetting-there.

Koske, I. et al. (2015), "The 2013 update of the OECD's database on product market regulation: Policy insights for OECD and non-OECD countries", OECD Economics Department Working Papers, No. 1200, OECD Publishing. DOI: http://dx.doi.org/10.1787/5js3f5d3n2vl-en.

Kraemer-Eis, H., F. Lang, S. Gvetadze (2015), "European Small Business Finance Outlook, June", European Investment Fund Working Paper 2015/28, available at www.eif.org/news_centre/publications/eif_wp_28.pdf.

Lazaretou, S. (2014), "The smart economy: cultural and creative industries in Greece. Can they be a way out of the crisis?", Bank of Greece Working Paper 175, February, available at www.bankofgreece.gr/BogEkdoseis/Paper2014175.pdf.

Manova, K. (2013), Credit Constraints, Heterogeneous Firms, and International Trade, Review of Economic Studies, 80, 711-744, available at www.nber.org/papers/w14531.

Massolution (2015), 2015 The Crowdfunding Industry Report, available at www.crowdsourcing.org/editorial/global-crowdfunding-market-to-reach-344b-in-2015-predictsmassolutions-2015cf-industry-report/45376.

Muûls, M. (2012), Exporters, Importers and Credit Constraints, Center for Economic Performance Discussion Paper, No 1169, available at http://cep.lse.ac.uk/pubs/download/dp1169.pdf.

Nassr, I.K. and G. Wehinger (2014), "Non-bank debt financing for SMEs: The role of securitisation, private placements and bonds. Discussions at an OECD Financial Roundtable", OECD Journal: Financial Market Trends, Vol. 2014/1. DOI: http://dx.doi.org/10.1787/fmt-2014-5jxx05svvw34.

Nassr, I.K. and G. Wehinger (2015a), "Unlocking SME finance through market-based debt: Securitisation, private placements and bonds", OECD Journal: Financial Market Trends vol. 2014/2. DOI: http://dx.doi.org/10.1787/fmt-2014-5js3bg1g53ln.

Nassr, I.K. and G.Wehinger (2015b), "Opportunities and Limitations of Public Equity Markets for SMEs", OECD Journal: Financial Market Trends vol.. . DOI: http://dx.doi.org/10.1787/fmt2015-5jrs051fvnjk.

National Documentation Centre (2015), Research, Technology and Innovation Performance of Greek SMEs: Making sense of available data, December.

NBG - National Bank of Greece (2014), Survey of Greek SMEs: First half 2014, July 2014, available at https://www.nbg.gr/greek/the-group/press-office/espot/reports/Documents/SMES 2014H1_en.pdf.

NBG - National Bank of Greece (2016), Act4Greece: a pioneering initiative by NBG, available at https://www.nbg.gr/english/the-group/press-office/press-releases/Pages/Act4Greece-apioneering-initiative-by-NBG.aspx

OECD (2007), Enhancing the role of SMEs in Global Value Chains, OECD Global Conference in Tokyo Background report, available at www.oecd.org/cfe/smes/38774814.pdf. 
OECD. (2009), Impact of the global crisis on SMEs and entrepreneurship financing and policy responses, Paris: OECD Publishing, available at www.oecd.org/cfe/smes/43183090.pdf.

OECD (2011), Financing High-Growth Firms: The Role of Angel Investors, available at www.oecdilibrary.org/industry-and-services/financing-high-growth-firms_9789264118782-en.

OECD (2012), OECD/INFE High-Level Principles on national strategies for financial education, August 2012, available at www.oecd.org/daf/fin/financial-education/OECD-INFE-PrinciplesNational-Strategies-Financial-Education.pdf.

OECD (2013a), OECD Science, Technology and Industry Scoreboard 2013, OECD Publishing, Paris. DOI: http://dx.doi.org/10.1787/sti_scoreboard-2013-en.

OECD (2013b), OECD Economic Surveys: Greece, OECD Publishing, Paris. DOI: http://dx.doi.org/10.1787/eco surveys-grc-2013-en

OECD (2013c), OECD-WTO Database on Trade in Value-Added, available at www.oecd.org/sti/ind/TIVA\%20flyer\%20FINAL.pdf.

OECD (2013d), Interconnected economies: benefiting from Global Value Chains, Synthesis report, available at www.oecd.org/sti/ind/interconnected-economies-GVCs-synthesis.pdf.

OECD (2014a), OECD Services Trade Restrictiveness Index (STRI): Greece, available at www.oecd.org/tad/services-trade/STRI_GRC.pdf.

OECD (2014b), Measurement and Reduction of Administrative Burdens in Greece: An Overview of 13 Sectors, OECD Publishing. Paris. DOI: http://dx.doi.org/10.1787/9789264213524-en

OECD (2014c), OECD Tourism Trends and Policies 2014, OECD Publishing, Paris. DOI: http://dx.doi.org/10.1787/tour-2014-enOECD (2014d), Science, Technology and Industry Outlook 2014, OECD Publishing, Paris. DOI: http://dx.doi.org/10.1787/sti_outlook-2014-en

OECD (2014e), Education at a Glance 2014: OECD Indicators, OECD Publishing, Paris. DOI: http://dx.doi.org/10.1787/eag-2014-en

OECD (2015a), OECD Economic Outlook, OECD Publishing, Paris. DOI: http://dx.doi.org/10.1787/eco_outlook-v2015-1-en

OECD (2015b), Entrepreneurship at a Glance 2015, OECD Publishing, Paris. DOI: http://dx.doi.org/10.1787/entrepreneur aag-2015-en

OECD (2015c), Financing SMEs and Entrepreneurs 2015, an OECD Scoreboard, OECD Publishing, Paris, DOI: http://dx.doi.org/10.1787/fin_sme_ent-2015-en

OECD (2015d), Financing SMEs and Entrepreneurs 2016, an OECD Scoreboard, OECD Publishing, Paris, forthcoming.

OECD (2015e), Opportunities and Constraints of Market-Based Financing for SMEs, OECD's Report to G20 Finance Ministers and Central bank Governors, September 2015, available at www.oecd.org/g20/meetings/antalya/Opportunities-and-Constraints-of-Market-basedFinancing-for-SMEs.pdf. 
OECD (2015f), New Approaches to SME and Entrepreneurship Financing: Broadening the Range of Instruments, available at www.oecd.org/cfe/smes/New-Approaches-SME-full-report.pdf

OECD (2015g), G20/OECD High Level Principles on SME Financing, OECD Progress Report to G20 Finance Ministers and Central Bank Governors, September 2015, available at www.oecd.org/g20/topics/financing-for-investment/G20-OECD-High-level-Principles-onSME-Financing-Progress-Report.pdf.

OECD (2015h), OECD Innovation Policy Platform - Cluster Policies, available at www.oecd.org/innovation/policyplatform/48137710.pdf.

OECD (2015i), Economy-wide regulation, OECD Product Market Regulation Statistics (database). DOI: http://dx.doi.org/10.1787/data-00593-en

OECD (2015j), OECD Science, Technology and Industry Scoreboard 2015, http://dx.doi.org/10.1787/sti_scoreboard-2015-en

OECD (2015k), Case Study on Crowdfunding, OECD Working Party on SMEs and Entrepreneurship (WPSMEE) document CFE/SME(2013)7/ANN1/FINAL (8 July); available at www.oecd.org/officialdocuments/publicdisplaydocumentpdf/?cote=CFE/SME(2013)7/ANN1/F INAL\&docLanguage $=$ En.

OECD (20151), "Crowdfunding for SMEs", in OECD, New Approaches to SME and Entrepreneurship Financing: Broadening the Range of Instruments, OECD Publishing, Paris.

DOI: http://dx.doi.org/10.1787/9789264240957-8-en

OECD (2016), OECD Economic Surveys: Greece 2016, OECD Publishing, Paris. DOI: http://dx.doi.org/10.1787/eco_surveys-grc-2016-en

Olloqui, F. d., \& Palma-Arancibia, C. (2012, May), Las nuevas oportunidades para las instituciones financieras de desarrollo en América Latina, Inter-American Development Bank, Sector de Instituciones para el Desarrollo; Notas Técnicas \#IDB-TN-402.

Robano, V. (2013), "The Role of Public Financial Institutions for SMEs", in Asian Development Bank, $A D B-O E C D$ study on enhancing financial accessibility for SMEs: Lessons from recent crises, available at: www.oecd.org/cfe/smes/adb-oecd-study-enhancing-financial-accessibilitysmes.pdf.

Stiglitz J. and A. Weiss (1981), "Credit Rationing in Markets with imperfect information", American Economic Review, 71(3) June pp. 393-410.

Tagkalakis, A. (2014), "Fiscal policy, net exports, and the sectoral composition of output in Greece", Bank of Greece Working Papers, September 2014, available at www.bankofgreece.gr/BogEkdoseis/Paper2014186.pdf.

WEF - World Economic Forum (2015), The Global Competitiveness Report 2014-2015, available at http://www3.weforum.org/docs/WEF_GlobalCompetitivenessReport_2014-15.pdf.

Wehinger, G. (2012), "Bank deleveraging, the move from bank to market-based financing, and SME financing", OECD Journal: Financial Market Trends, Vol. 2012/1. DOI: http://dx.doi.org/10.1787/fmt-2012-5k91hbvfh9g3 
Wilson, K. E. and F. Silva (2013), "Policies for Seed and Early Stage Finance: Findings from the 2012 OECD Financing Questionnaire", OECD Science, Technology and Industry Policy Papers, No. 9, OECD Publishing, Paris. DOI: http://dx.doi.org/10.1787/5k3xqsf00j33-en 


\section{WORKING PAPERS PUBLISHED TO DATE}

The full series is listed below in chronological order. Prior to March 2010, the series was named OECD Working Papers on Insurance and Private Pensions. All working papers can be accessed online at: www.oecd.org/daf/fin/wp.

2016

WP40: Financial education policies in Asia and the Pacific

2015

WP39: Financial Education for Long-term Savings and Investments: Review of Research and Literature

WP38: Financial Education for Migrants and their Families

2014

WP37: The Bitcoin Question: Currency versus Trust-less Transfer Technology 2013

WP36: Institutional Investors and Infrastructure Financing

WP35: Institutional Investors and Green Infrastructure Investments: Selected Case Studies

WP34: Promoting Financial Inclusion through Financial Education

WP33: Financial Education in Latin America and the Caribbean

WP32: Pension Fund Investment in Infrastructure: A Comparison between Australia and Canada

WP31: Policyholder Protection Schemes: Selected Considerations

2012

WP30: The Effect of Solvency Regulations and Accounting Standards on Long-Term Investing

WP29: Trends in Large Pension Fund Investment in Infrastructure

WP28: Communicating Pension Risk to DC Plan Members: The Chilean Case of a Pension Risk Simulator

WP27: The Role of Funded Pensions in Retirement Income Systems: Issues for the Russian Federation

WP26: Infrastructure Investment in New Markets: Challenges and Opportunities for Pension Funds

WP25: The Status of Financial Education in Africa

WP24: Defining and Measuring Green Investments: Implications

for Institutional Investors' Asset Allocations

WP23: The Role of Institutional Investors in Financing Clean Energy 
WP22: Defining and Measuring Green Investments: Implications for Institutional Investors' Asset Allocations

WP21: Identification and Assessment of Publicly Available Data Sources to Calculate Indicators of Private Pensions

WP20: Coverage of Private Pensions Systems: Evidence and Policy Options

WP19: Annual DC Pension Statements and the Communications Challenge

WP18: Lessons from National Pensions Communication Campaigns

WP17: Review of the Swedish National Pension Funds

WP16: Current Status of National Strategies for Financial Education

WP15: Measuring Financial Literacy: Results of the OECD International Network on Financial Education (INFE) Pilot Study

WP14: Empowering Women through Financial Awareness and Education

WP13: Pension Fund Investment in Infrastructure: Policy Actions

WP12: Designing Optimal Risk Mitigation and Risk Transfer Mechanisms to Improve the Management of Earthquake Risk in Chile

2011

WP11: The Role of Guarantees in Defined Contribution Pensions

WP10: The Role of Pension Funds in Financing Green Growth Initiatives

WP9: Catastrophe Financing for Governments

WP8: Funding in Public Sector Pension Plans - International Evidence

WP7: Reform on Pension Fund Governance and Management: The 1998 Reform of Korea National Pension Fund

WP6: Options to Improve the Governance and Investment of Japan's Government Pension Investment Fund

WP5: The New IAS 19 Exposure Draft

WP4: The EU Stress Test and Sovereign Debt Exposures

WP3: The Impact of the Financial Crisis on Defined Benefit Plans and the Need for CounterCyclica Funding Regulations

WP2: Assessing Default Investment Strategies in Defined Contribution Pension Plans

WP1: Framework for the Development of Financial Literacy Baseline Surveys: A First International Comparative Analysis

OECD Working Papers on Insurance and Private Pensions

2010

WP41: Policy Action in Private Occupational Pensions in Japan since the Economic Crisis of the 1990s

WP40: Pension Funds' Risk-management Framework: Regulation and Supervisory Oversight WP38: Managing Investment Risk in Defined Benefit Pension Funds 
WP37: Investment Regulations and Defined Contribution Pensions

WP36: Private Pensions and Policy Responses to the Financial and Economic Crisis

WP35: Defined-contribution (DC) arrangements in Anglo-Saxon Countries

WP34: Evaluating the Design of Private Pension Plans

WP33: Licensing Regulation and the Supervisory Structure of Private Pensions

WP32: Pension Fund Investment in Infrastructure

WP31: Pension Coverage and Informal Sector Workers

WP30: Pensions in Africa

WP29: Ageing and the Payout Phase of Pensions, Annuities and Financial Markets

2008

WP27: Fees in Individual Account Pension Systems

WP26: Forms of Benefit Payment at Retirement

WP25: Policy Options for the Payout Phase

WP24: National Annuity Markets

WP23: Accounting for Defined Benefit Plans

WP22: Description of Private Pension Systems

WP21: Comparing Aggregate Investment Returns in Privately Managed Pension Funds

WP20: Pension Fund Performance

WP19: Coverage of Funded Pension Plans

WP18: Pension Fund Governance

WP17: Funding Regulations and Risk Sharing

WP16: Evaluating the Impact of Risk Based Funding Requirements on Pension Funds

WP15: Governance and Investment of Public Pension Reserve Funds in Selected OECD Countries

WP14: Sovereign Wealth and Pension Fund Issues

2007

WP13: Reforming the Valuation and Funding of Pension Promises

WP12: Pension Fund Investment in Hedge Funds

WP11: Implications of Behavioural Economics for Mandatory Individual Account Pension Systems

WP10: Portfolio Investment in an Intertemporal Setting

WP9: Collective Pension Funds

WP8: Pension Fund Regulation and Risk Management

WP7: Survey of Investment Choice by Pension Fund Members

WP6: Benefit Protection

WP5: Benefit Security Pension Fund Guarantee Schemes 
WP4: Governments and the Market for Longevity-Indexed Bonds

WP3: Longevity Risk and Private Pensions

WP2: Policy Issues for Developing Annuities Markets

2006

WP1: Funding Rules and Actuarial Methods 